Research article urn:1sid:zoobank.org:pub:10676882-F6AC-4BC8-A0F1-9C0882EA36C2

\title{
Kryptonesticus deelemanae gen. et sp. nov. (Araneae, Nesticidae), with notes on the Mediterranean cave species
}

\author{
Martina PAVLEK ${ }^{1, *} \&$ Carles RIBERA ${ }^{2}$ \\ ${ }^{1}$ Ruđer Bošković Institute, Bijenička 54, 10000 Zagreb, Croatia; and \\ Croatian Biospeleological Society, Demetrova 1, 10000 Zagreb, Croatia. \\ ${ }^{2}$ Institut de Recerca de la Biodiversitat, Departament de Biologia Animal, \\ Universitat de Barcelona, Av. Diagonal, 643, Barcelona-08028, Spain. \\ *Corresponding author: mpavlek@irb.hr \\ ${ }^{2}$ Email: cribera@ub.edu \\ ${ }^{1}$ urn:lsid:zoobank.org:author:681A5613-37C0-4684-B3B5-8BBE6BEAB4BB \\ ${ }^{2}$ urn:1sid:zoobank.org:author:509826D6-1E4D-4201-B08C-07D0F0044CC7
}

\begin{abstract}
This paper describes and illustrates a new genus and a new species belonging to the family Nesticidae based on morphology and supported by molecular data. The new genus, Kryptonesticus gen. nov., groups eight species spread from Bulgaria and Turkey to Croatia, including Montenegro, Bosnia and Herzegovina and Crete. As a result, seven new combinations are proposed: K. eremita (Simon, 1879) comb. nov., K. arenstorffi (Kulczyński, 1914) comb. nov., K. fagei (Kratochvíl, 1933) comb. nov., K. beroni (Deltshev, 1977) comb. nov., K. beshkovi (Deltshev, 1979) comb. nov., K. henderickxi (Bosselaers, 1998) comb. nov. and $K$. dimensis (López-Pancorbo, Kunt \& Ribera, 2013) comb. nov., all ex Nesticus. Kryptonesticus deelemanae gen. et sp. nov. is described on the basis of both sexes and its phylogenetic relationships with closely related species are discussed based on morphological and molecular data (the coxl, rrn and $H 3$ genes). In addition, the species of this new genus (except for $K$. eremita) are clear candidates for protection: they have highly restricted ranges and some of them show a high degree of adaptation to the subterranean environment.
\end{abstract}

Keywords. Nesticidae, taxonomy, caves, endemism, Dinarides.

Pavlek M. \& Ribera C. 2017. Kryptonesticus deelemanae gen. et sp. nov. (Araneae, Nesticidae), with notes on the Mediterranean cave species. European Journal of Taxonomy 262: 1-27. http://dx.doi.org/10.5852/ejt.2017.262

\section{Introduction}

The Nesticids inhabit dark and damp places and are common cave-dwellers in the northern Mediterranean Basin. So far, 52 different species belonging to four genera have been discovered in this area: Nesticus Thorell, 1869, Typhlonesticus Kulczyński, 1914, Carpathonesticus Lehtinen \& Saaristo, 1980 and Aituaria Esyunin \& Efimik, 1998 (World Spider Catalog 2016). As far as we know, only one of these 52 species (C. lotriensis Weiss, 1983) has not been recorded in caves because it lives in a non-karstic area, although it is usually found in the walls and ceilings of hollows in rocky walls in shaded areas within 
its distribution range. Two more genera occur in bordering areas: Canarionesticus Wunderlich, 1992, endemic to the Tenerife (Canaries), and Nesticella Lehtinen \& Saaristo, 1980, which is broadly spread throughout the Asian continent and recorded in Azerbaijan (N. moguera (Yaginuma, 1972)).

At the species level, most of them are well described and illustrated, but the taxonomy of the whole group is not well established at the genus level. With only a cursory review of the Mediterranean Nesticus species, we realize that there are conspicuous differences in both male and female genital morphology, suggesting the existence of independent evolutionary lineages. These morphological differences were already pointed out by Lehtinen \& Saaristo (1980), and López-Pancorbo \& Ribera (2011).

In the Dinarides seven nesticid species have been recorded so far: two Typhlonesticus species, the type species of the genus T. absoloni (Kratochvíl, 1933) from Montenegro, and T. idriacus (Roewer, 1931) from Slovenia; one Carpathonesticus species, C. parvus (Kulczyński, 1914) from Bosnia and Herzegovina; and four Nesticus species, two widespread species, N. cellulanus (Clerck, 1757) and N. eremita Simon, 1879, and two narrowly distributed species, N. arenstorffi Kulczyński, 1914 from Bosnia and Herzegovina and Montenegro and N. fagei Kratochvíl, 1933 from Bosnia and Herzegovina. In Croatia, only N. cellulanus and N. eremita have been recorded so far (Nentwig et al. 2016). Nesticus speluncarum Pavesi, 1873, an endemic species from a small part of Italy, is wrongly listed for Dinaric countries, probably because of the misidentification of $N$. eremita samples. The most relevant authors in taxonomic studies of Dinaric nesticids are Władysław Kulczyński and Josef Kratochvíl. Kulczyński described two species (Kulczyński 1914) while Kratochvíl's 1933 paper, besides the description of two new species from Dinarides, gave an overview of all European nesticids known at that time and divided species of Nesticus into three groups based mostly on paracymbium morphology: the hercynian, dinaric and transylvanic groups (Kratochvíl 1933). In later papers, he made a great contribution to the distribution areas of the known species (Kratochvíl 1934, 1935) and compared the body coloration and leg length of different nesticid species, which he related to their adaptation to cave life (Kratochvíl 1978).

Research of the Croatian cave fauna, including cave spiders, intensified with the foundation of the Croatian Biospeleological Society (CBSS) in 1996. One of the intensively researched areas is Biokovo Mountain, known for its large number of endemic and relict taxa from many cave dwelling groups of animals (Ozimec \& Jalzic 1999). The result of a project, "Inventory and Mapping of the Subterranean and Spring Fauna", undertaken by CBSS and the Biokovo Nature Park, as well as later field trips, was the discovery of many interesting and new cave taxa that included a new nesticid species.

This discovery prompted us to perform a review of the species described so far, especially those showing a strong morphological similarity. These were N. fagei Kratochvíl, 1933 and N. arenstorffi Kulczyński, 1914, two species geographically and morphologically closest to the new one, but also $N$. henderickxi Bosselaers, 1998, N. dimensis López-Pancorbo, Kunt \& Ribera, 2013, N. eremita Simon, 1879, N. beroni Deltshev, 1977 and $N$. beshkovi Deltshev, 1979. In order to check the evolutionary relationships between these species, a molecular phylogenetic analysis based on nuclear and mitochondrial gene sequences was performed, including the type species of the Mediterranean genera Nesticus ( $N$. cellulanus), Typhlonesticus (T. absoloni) and Carpathonesticus (C. fodinarum).

This paper aims to describe a new genus and a new species belonging to the Nesticidae. The new genus, Kryptonesticus gen. nov., shows conspicuous and synapomorphic characters in male and female genital organs that allow a clear differentiation from other nesticid genera, which is why we propose seven new combinations of the above mentioned species. Finally, the new species is related to the geographically closest species, $N$. fagei and $N$. arenstorffi, for which we also provided redescriptions of both sexes. 


\section{Material and methods}

\section{Molecular data}

\section{Sampling and molecular data collection}

In order to assess the phylogenetic affinities of the new genus we conducted molecular analysis on representatives of the Mediterranean genera Nesticus, Carpathonesticus and Typhlonesticus, including the type species from each of them. We could not include representatives of the genus Aituaria due to lack of suitable material for molecular analysis. We also included all representatives of the new genus, except $N$. beshkovi and $N$. beroni due to lack of specimens.

Specimens were collected in the field, fixed in $96 \%$ or absolute ethanol and stored at $4{ }^{\circ} \mathrm{C}$. Total genomic DNA was extracted with QIamp ${ }^{\circledR}$ DNA Mini Kit and DNeasy Blood \& Tissue Kit (QIAGEN) following the manufacturer's protocols. The approximate concentration and purity of the DNA obtained were verified using 1\% agarose/TBE gel electrophoresis and a BioSpec-nano Spectrophotometer.

Partial fragments of two mitochondrial (cytochrome oxidase I: coxl and 16S rRNA: $r r n L$ ) and one nuclear (Histone 3: H3) gene were selectively amplified in polymerase chain reactions (PCR) that were conducted following Ribera et al. (2014) and sequenced at the Macrogene sequence center in the Netherlands. Raw sequences were edited and assembled with Geneious v. 4.6 .5 (http://www.geneious. com; Kearse et al. 2012). All new sequences obtained were deposited in GenBank (see Appendix 1 for localities and GenBank accession numbers of all used samples).

\footnotetext{
Alignment, partitioning analyses and evolutionary model selection

Alignment of the coxl and $H 3$ gene fragments was trivial due to the absence of length polymorphism. The $r r n L$ sequences were aligned using the online version of MAFFT, applying the Q-INS-i algorithm (Katoh \& Toh 2008) with the default options. With the "user-specific schemes" option in PartitionFinder v. 1.0.1 (Lanfear et al. 2012), we explored eight alternative partitioning schemes. Partitioning schemes ranged from all the gene fragments together as one partition, to a highly partitioned scheme, with each gene fragment considered as an independent partition and the third codon position separated from the first and second in cox 1 and $H 3$. We used the Bayesian information criterion to select among the partition schemes and evolutionary models (Lanfear et al. 2012). We obtained the uncorrected pairwise (p)distance genetic divergences between and within evolutionary lineages using MEGA v. 7.0.14 (Kumar et al. 2016) removing alignment gaps in pairwise comparisons.
}

\section{Phylogenetic analyses}

A Maximum Likelihood (ML) analysis was performed using RAxML v. 7.4.2 (Stamatakis 2006), through the graphical front-end RAxMLGUI 1.3; Silvestro \& Michalak 2012). The GTR + G nucleotide substitution model was applied to each of the partitions corresponding to the best partition scheme selected and nonparametric bootstrap support analysis of 1000 pseudoreplicates was conducted. Typhonesticus absoloni was used to root the tree.

\section{Morphological observations}

All measurements are in millimeters (mm). Specimens were hand collected using forceps. Body color descriptions were based on live observations and digital images taken in situ with a Canon Eos 400D camera.

The vulva was removed and treated with $30 \% \mathrm{KOH}$. After observation, drawing and taking photographs, the vulva was washed in distilled water and stored in $70 \%$ ethanol. The left male palp was illustrated and photographed in all cases. Terminology for the body measurements and copulatory organs follows López-Pancorbo \& Ribera (2011). 
Specimens were examined under a Zeiss Stereo Discovery V12 stereo microscope equipped with an Infinity X DeltaPix digital camera and under a Zeiss SteREO Discovery V20 stereo microscope equipped with an Axiocam 105 color microscopy camera. The digital microscopic images were edited using DeltaPix DpxWiew Pro AZ v. 13.6 software with an enhanced focus function. For viewing and tracking the insemination ducts a Leitz DMRB Progres C3 microscope equipped with a digital camera was used. The drawings were hand-drawn in ink using a "camera lucida" attached to the Leica MZ160A binocular stereoscope.

\section{Abbreviations used}

$\mathrm{b}=$ bulge in the inner MA side

BTA $=$ basal tegular apophysis

$\mathrm{dm}=$ dorsomedian apophysis of do

do $\quad=$ dorsal paracymbium process

$\mathrm{E} \quad=$ embolus

id $\quad=$ insemination duct

juv. $\quad=$ juv.enile

$\operatorname{lr} \quad=$ longitudinal ridge of tegulum

MA $=$ median apophysis

me $=$ membranous extension of ventral process

od $=$ oval depression

$\mathrm{OL} \quad=$ opisthosoma length

OW $=$ maximum opisthosoma width

$\mathrm{P} \quad=$ paracymbium

$\mathrm{PL}=$ prosoma length (from the posterior edge of the carapace to the front edge of the clypeus, measured at the midline)

poe $\quad=$ pointed outer MA edge

$\mathrm{PW} \quad=$ maximum prosoma width

rs $\quad=$ round swelling of tegulum

$\mathrm{S} \quad=$ spermathecae

$\mathrm{T}=$ tegulum

$\mathrm{TL}=$ total body length

TTA $=$ theridioid tegular apophysis

TTA $1=$ process 1 of TTA

TTA $22=$ process 2 of TTA

$\mathrm{V} \quad=$ ventral paracymbium process

$\mathrm{wr}=$ wrinkled outer rim of MA proximal part

Eyes

$\mathrm{AL}=$ anterior lateral

$\mathrm{AM}=$ anterior median

$\mathrm{PL}=$ posterior lateral

$\mathrm{PM}=$ posterior median

\section{Collection acronyms}

CBSS = Croatian Biospeleological Society collection, part of the Croatian Natural History Museum collection, Zagreb, Croatia

$\mathrm{SMF}=$ Senckenberg Museum, Frankfurt, Germany 
PAVLEK M. \& RIBERA C., A new genus and species of Nesticidae

\title{
Results
}

\author{
Class Arachnida Cuvier, 1812 \\ Order Araneae Clerck, 1757 \\ Family Nesticidae Simon, 1894 \\ Kryptonesticus gen. nov. \\ urn:1sid:zoobank.org:act:19EABFE7-08F7-4AB8-860B-0AB2E59EBC03
}

Figs $1-5$

\section{Type species}

Kryptonesticus deelemanae gen. et sp. nov.

\section{Diagnosis}

Kryptonesticus gen. nov. differs from other nesticid genera by the morphology of both male and female copulatory organs. In males, the most conspicuous diagnostic character is the shape and size of the median apophysis (MA), which is large and conspicuous, highly developed and thickly sclerotized, emerging from the middle part of the tegulum and reaching its apical part. This characteristic is shared among a group of species including $K$. eremita, $K$. dimensis, $K$. henderickxi, $K$. fagei and $K$. arenstorff (males of $K$. beshkovi and $K$. biroi are unknown). In other nesticid genera, the MA is absent, inconspicuous or poorly developed (Nesticella Lehtinen \& Saaristo, 1980; Wraios Ballarin \& Li, 2015; Nescina Ballarin \& Li, 2015; Hamus Ballarin \& Li, 2015; Gaucelmus Keyserling, 1884; Cyclocarcina Komatsu, 1942; Typhlonesticus Kulczyński, 1914; Canarionesticus Wunderlich, 1992); in the form of a small, curved and pointed hook (Carpathonesticus Lehtinen \& Saaristo, 1980); compact, transverse and not very developed (Eidmannella Roewer, 1935); more conspicuous and transverse (Aituaria Esyunin \& Efimik, 1998) or it is well developed (Nesticus cellulanus (Clerck, 1757) and Pseudonesticus Liu \& Li, 2013), but in this case the MA is long, thin and extended laterally. In Kryptonesticus gen. nov., the MA extends laterally at its base and then stretches towards the apex of the tegulum, parallel to the embolus. The theridioid tegular apophysis (TTA) is more compact than in N. cellulanus or Pseudonesticus. This is a very important character, since the TTA and MA are actively involved in sperm transfer (Huber 1993). Kryptonesticus gen. nov. also differs from other nesticid genera in the shape, ramification and modifications associated with the paracymbium. Kryptonesticus gen. nov. shows a well-developed dorsal process and a poorly differentiated ventral one. Distal and paradistal apophyses are absent and the dorsomedian apophysis is short and pointed, inconspicuous or absent. Females of this new genus show characteristic slender spermathecae, oval-shaped, with a shallow constriction in the middle, located above or just behind the apical part of the internal chitinous structures of the vulva. Insemination ducts depart from the basal part of the spermathecae, make a sharp turn-out and continue ventro-laterally, reaching the copulatory orifices.

\section{Etymology}

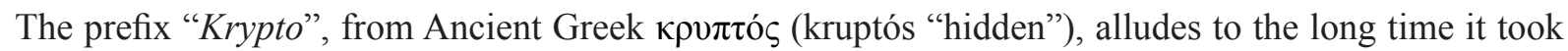
to diagnose this evolutionary line.

\section{Distribution}

From Bulgaria and Turkey to Croatia, including Montenegro, Bosnia and Herzegovina and Crete. All these species are known only from the type locality, or have small distribution ranges. K. eremita is an exception; this species is linked to human activities and can be found in hangars, cellars and cottages. It has been cited from France and Italy to Bulgaria and Turkey. It is a potentially invasive species, found in an abandoned air-raid tunnel in Auckland, New Zealand (Vink \& Dupérré 2011). 


\section{Taxonomic remarks}

The morphology of both male and female copulatory organs of this group of species shows important differences with respect to $N$. cellulanus (the type species of the genus Nesticus) and the western Mediterranean Nesticus species, as well as the representatives of Carpathonesticus and Typhlonesticus. The asymmetrical development of the paracymbial ramification, the shape, size and arrangement of the median apophysis and some differences in the size and arrangement of the TTA p1 and p2 processes constitute the major differences in males. The number and position of spermathecae and the features of the insemination ducts are the most obvious characteristics in females. K. beroni and K. beshkovi are only known from females. Regardless, the shape and position of the spemathecae and the insemination ducts undoubtedly allow us to transfer these two species to the Kryptonesticus evolutionary lineage.

Concerning species of Nesticus from other parts of the world (e.g., East Asia, North and South America) we can state that they do not show the diagnostic characters of the new genus described here. Surely this is a polyphyletic group that could be considered as a wastebasket group, and its inclusion within the genus Nesticus must be revised since the morphology of their genitalia is remarkably different from the type species of the genus ( $N$. cellulanus). Of course, this affirmation must be tested in a phylogenetic framework including all species of Nesticus described so far. Preliminary results on the phylogeny of European nesticids, including some American and Asian representatives (results not shown), indicate the polyphyly of Nesticus species described from other parts of the world.

\section{Composition}

Kryptonesticus deelemanae gen. et sp. nov., K. eremita (Simon, 1879) comb. nov. (Southern and Central Europe, introduced in New Zealand, potentially invasive species), K. arenstorffi (Kulczyński, 1914) comb. nov. (Bosnia and Herzegovina and Montenegro), K. fagei (Kratochvíl, 1933) comb. nov. (Bosnia and Herzegovina), K. beroni (Deltshev, 1977) comb. nov. (Bulgaria), K. beshkovi (Deltshev, 1979) comb. nov. (Crete), K. henderickxi (Bosselaers, 1998) comb. nov. (Crete) and K. dimensis (LópezPancorbo, Kunt \& Ribera, 2013) comb. nov. (Turkey).

Krypyonesticus deelemanae gen. et sp. nov. urn:1sid:zoobank.org:act:BAC5D31D-7A59-4FE7-BE9A-CB6167484170

Figs $1,2 \mathrm{~A}, 3 \mathrm{~A}-\mathrm{C}, 4 \mathrm{~A}, \mathrm{D}, 5 \mathrm{~A}, \mathrm{D}$

\section{Diagnosis}

The most prominent character of the male bulb is a large and conspicuous median apophysis which emerges from the middle part of the tegulum and reaches its apical part. The most obvious differences between the new species and the closest ones, $K$. fagei and $K$. arenstorffi, are: distal part of MA in the new species is massive and slightly thinner toward the top, while in $K$. arenstorffi the whole distal part is slender and the top is more narrowed; the proximal part of MA of the new species has a round process on the outer edge, while in $K$. fagei and K. arenstorff it has no process. Another important feature is the tooth-like dorsomedian apophysis of the paracymbium's dorsal process, which is not present in $K$. fagei and $K$. arenstorffi. The inner side of the distal part of MA, the curve between the proximal and distal parts of MA, the shape of the tegulum, the basal tegular apophysis and the dorsal paracymbium process are also diagnostic. The epigyne is most similar to that in $K$. fagei and $K$. arenstorffi, from which it differs in the outline of the posterior epigyne margin which is triangular in K. fagei and sinuous in other two species. The difference between the new species and $K$. arenstorff is in the posterior epigyne border, lateral of the central chitinous arches, which is straight in the new species and slightly notched in $K$. arenstorffi. The vulva can be distinguished by the position of the spermathecae, whose apical part in the new species reaches over the vulvar chitinous structures, while it does not in $K$. fagei and K. arenstorffi. 


\section{Etymology}

The specific name is a patronym in honor of Christa Laetitia Deeleman-Reinhold, an important Dutch arachnologist and a dear friend. Her work has vastly raised the knowledge of the cave spider fauna of Dinarides. The species name is in possessive genitive.

\section{Material examined}

\section{Holotype}

CROATIA: 1 đ̊, Biokovo Mt, Samogorska špilja, 4319'5.71" N, 17²'29.9” E, elevation 717 m, 23 Jan. 2016, leg. Marko Lukić (CBSS/AR 3934-1).

\section{Paratypes}

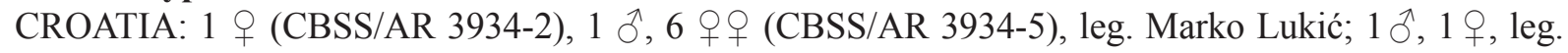
Marko Lukić (SMF); 1 ô, 7 우, leg. Tin Rožman (CBSS/AR 3932). All with same collection data as the holotype.

\section{Other material examined}

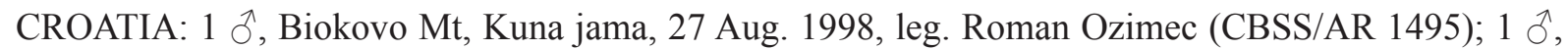
Biokovo Mt, Crna Ledenica, 24 Oct. 2006, leg. Marko Lukić (CBSS/AR 1277); 1 đ̂, Biokovo Mt, Stonjska peć donja, 27 Oct. 2003, leg. Roman Ozimec (CBSS/AR 1287).

\section{Comparative material}

TURKEY: $K$. dimensis (López-Pancorbo, Kunt \& Ribera, 2013), 1 § , 1 q, Antalya Province, Alanya District, Kestel Town, Dim Valley, Dim Cave, 3 Dec. 2011, leg. Kadir Boğaç Kunt.

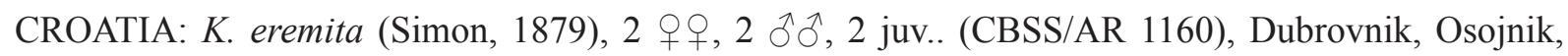
Močiljska špilja, 21 June 2001, leg. Roman Ozimec. K. arenstorffi (Kulczyński, 1914) and K. fagei (Kratochvíl, 1933): see below.

\section{Description}

\section{Male (holotype)}

Coloration. Carapace uniform whitish, opisthosoma yellowish without marked darker patches. Sternum of the same color as carapace. Appendages slightly darker, especially the distal segments (Fig. 1A).

Prosoma. Approximately circular in dorsal view. Cephalic region not differentiated from rest of prosoma. Fovea and thoracic grooves visible. Eyes normally developed. Eye size and interocular distances: $\mathrm{AM}=$
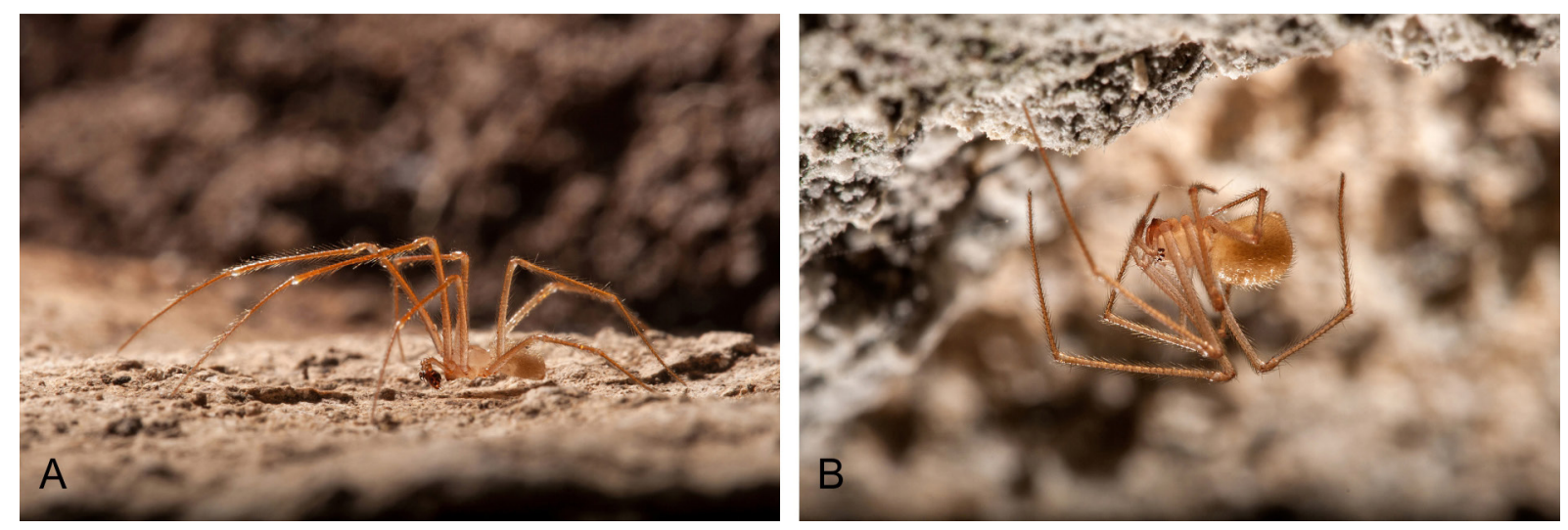

Fig 1. Habitus of Kryptonesticus deelemanae sp. nov. A. Male, body length $3.6 \mathrm{~mm}$. B. Female, body length $4.3 \mathrm{~mm}$. (Photos by M. Pavlek.) 
$0.042 ; \mathrm{AL}=0.081 ; \mathrm{PM}=0.085 ; \mathrm{PL}=0.077 ; \mathrm{AM}-\mathrm{AL}=0.07 ; \mathrm{AM}-\mathrm{AM}=0.067 ; \mathrm{PM}-\mathrm{PL}=0.075 ; \mathrm{PM}-$ $\mathrm{PM}=0.129 ; \mathrm{PL}-\mathrm{AL}=0.02$.

Opisthosoma. Sub-elliptical in dorsal view.

Chelicera. Mesal part of promargin with three teeth of about the same size.

Male palP. Paracymbium with a well-developed dorsal and very simple ventral processes. Dorsal process with two branches, apical branch parallel to cymbium's longer axis and shorter basal branch pointing to cymbium. Apical branch with parallel rims in proximal part, slightly dilated in middle with distal part acuminated, dagger-shaped. Basal branch with convex upper rim and with distal part sharp and tilted upward (Figs 2A, 3B). Dorsomedian apophysis tooth-like, small with broad base. Ventral process (Figs 2A, 3A) broad, rounded, with transparent middle part and a membranous extension on rim (Figs 2A, 3A). Tegulum with a shallow, rounded and broad longitudinal groove (visible in apical view, Fig. 3C) and with a broad, roughly circular basal apophysis on base (in ventral view). Median apophysis remarkably well developed, V-shaped, distal arm reaching almost to apical part of tegulum. Proximal part of MA with wrinkled outer rim which in posterior view looks like a small process. Outer edge between proximal and distal part equally rounded, distal part of MA mildly narrowing toward top, bluntly ended, with slightly serrated upper edge. Inner side of distal part of MA slightly swollen. Conductor absent. TTA with two processes: TTA p1 and TTA p2 (homologous to processes $\mathrm{p} 1-\mathrm{p} 6$ of the conductor complex in Huber 1993). TTA p1 saddle-shaped, longer than wide, with slim, rounded and pale process on top and in central area with three small dark teeth in a row, middle one smallest and proximal one faintly rounded. TTA p2 located in an apical position, with one sharp and pointed process, the rest forming groove where tip of embolus lodges and which serves as a conductor. Filamentous embolus partially borders tegulum and reaches its apex in semicircular course (Figs 2A, 3A). Measurements: PL: 1.552; PW: 1.407; OL: 2.075; OW: 1.412; TL = 3.627. Leg formula: I $>$ IV $>$ II $>$ III.

\begin{tabular}{ccccccccc}
\hline Leg & coxa & troch. & femur & patella & tibia & meta. & tarsus & total \\
\hline I & 0.18 & 0.18 & 4.20 & 0.66 & 4.32 & 4.12 & 1.52 & 15.18 \\
II & 0.17 & 0.20 & 3.24 & 0.60 & 2.97 & 2.91 & 1.20 & 11.30 \\
III & 0.17 & 0.14 & 2.54 & 0.53 & 1.88 & 2.12 & 0.91 & 8.30 \\
IV & 0.20 & 0.17 & 3.46 & 0.61 & 2.92 & 2.83 & 1.15 & 11.34 \\
\hline
\end{tabular}

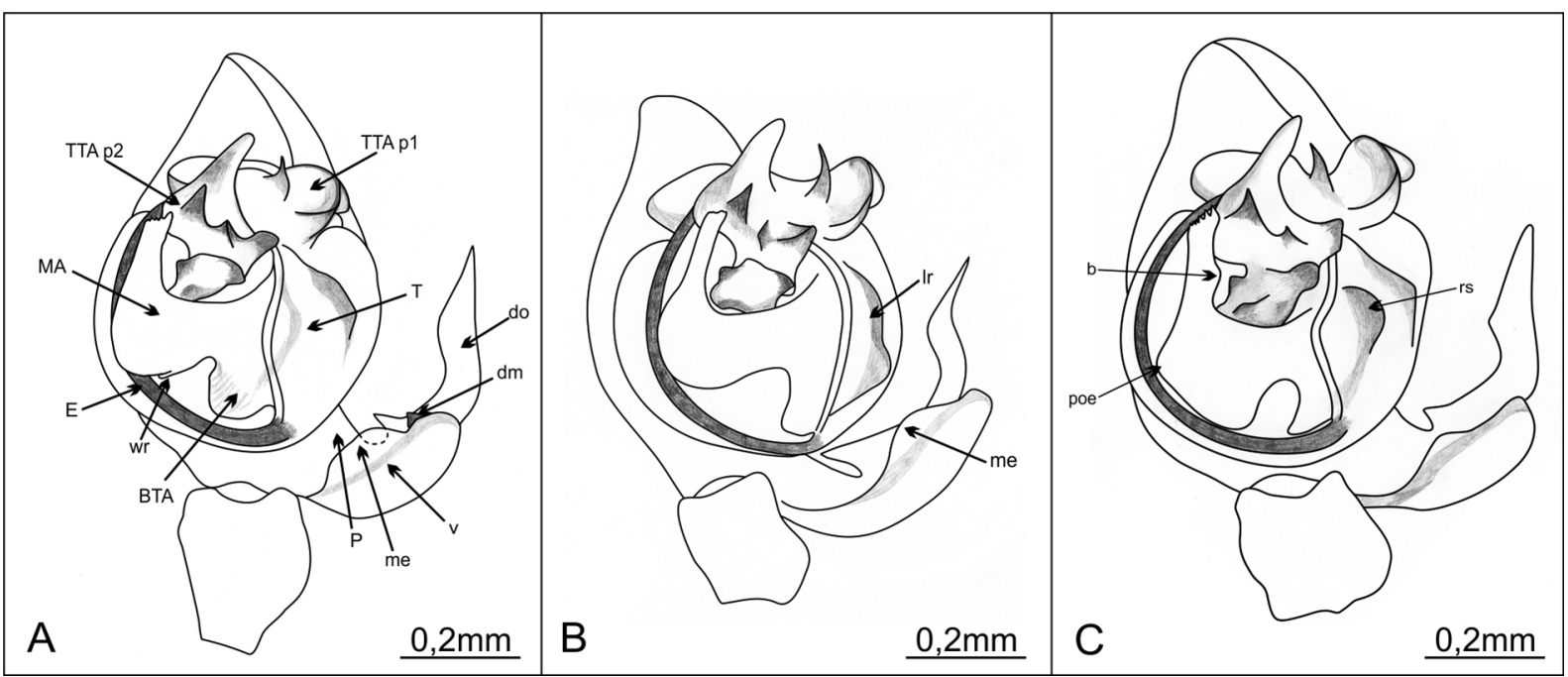

Fig 2. Male bulbus. A. Kryptonesticus deelemanae gen. et sp. nov. B. K. fagei (Kratochvíl, 1933). C. $K$. arenstorffi (Kulczyński, 1914). 
Female (paratype CBSS/AR 3934-2)

Somatic Characters (Fig. 1B) As in male, except that eye size and interocular distances are a bit different and body length a little larger: $\mathrm{AM}=0.052 ; \mathrm{AL}=0.095 ; \mathrm{PM}=0.085 ; \mathrm{PL}=0.076 ; \mathrm{AM}-\mathrm{AL}=0.061$;
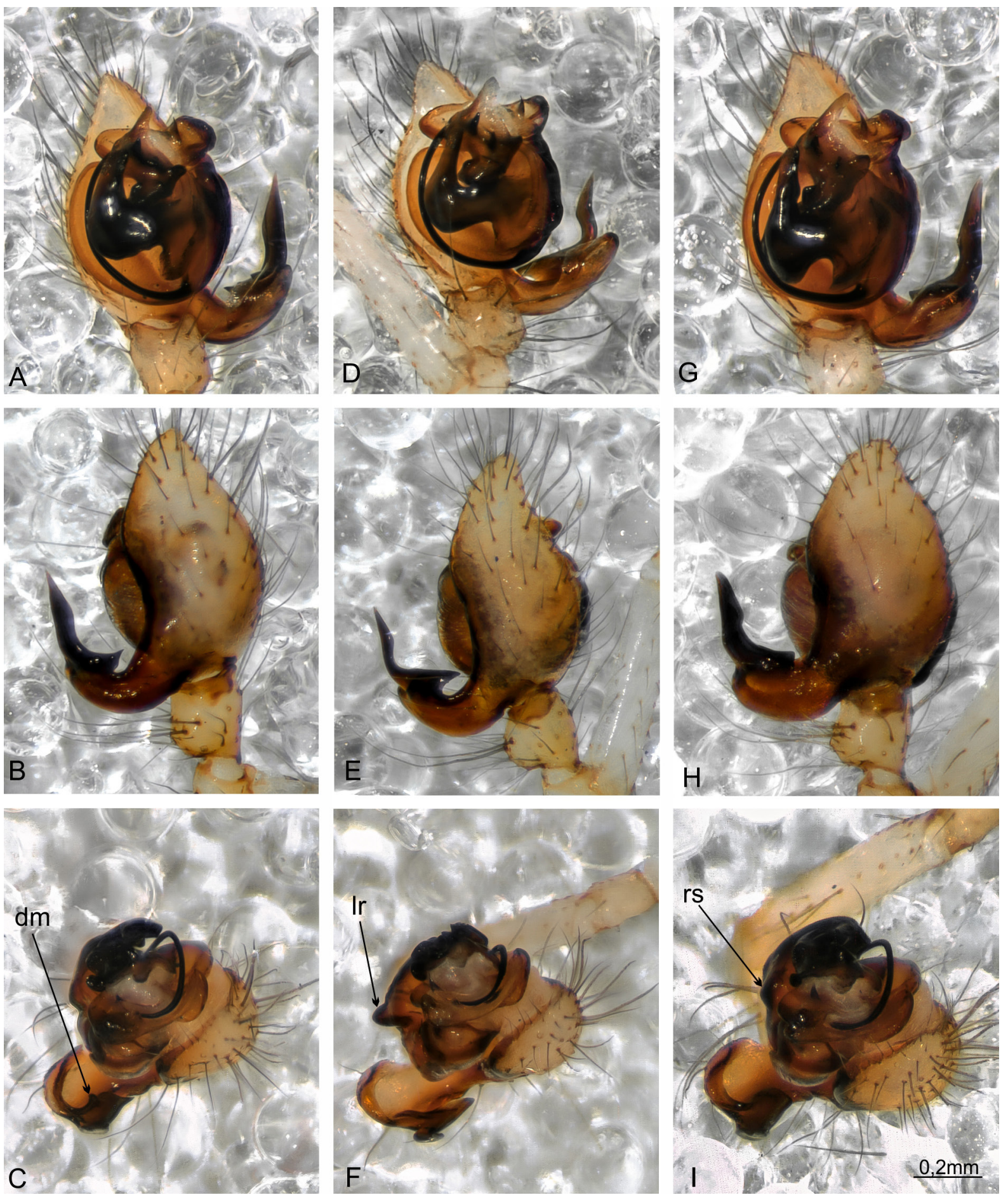

Fig 3. Male bulbus. A-C. Krytponesticus deelemanae gen. et sp. nov. D-F. K. fagei (Kratochvíl, 1933). G-I. K. arenstorffi (Kulczyński, 1914). A, D, G. Ventral view. B, E, H. Dorsal view. C, F, I. Apical view. The scale (shown on I) is the same for all photos. 
$\mathrm{AM}-\mathrm{AM}=0.070 ; \mathrm{PM}-\mathrm{PL}=0.128 ; \mathrm{PM}-\mathrm{PM}=0.1112 ; \mathrm{PL}-\mathrm{AL}=0.015$. Epigyne slightly wider than long, in lateral view not much protruding (Fig. 5D). Lateral lobes with oval depressions in posterior part, reaching middle of epigyne. Posterior epigyne border made of two semicircular chitinous arches, flanking depressions, coming together in middle and forming a small, pale, inconspicuous convex tubercule. A ridge apically bordering tubercle and depressions faintly visible. Epigyne outline, laterally from semicircular chitinous arches, straight, with no notches (Figs 4A, 5A-B).

VuLVA. Lateral sides of vulva made of compact dark chitinous structures enclosed in a firm transparent membrane (lateral pouches). Oval shaped spermathecae, with a shallow constriction in middle, located just above chitinous vulval structures (dorsal view). Narrower, upper part of spermathecae protrudes above chitinous vulval structures (Fig. 5C). Insemination ducts depart from spermathecae at bottom (Fig. 5C), make a sharp turn outwards and continue ventro-laterally in semicircular course to reach copulatory orifices (Fig. 4D). In ventral view, spermathecae slightly visible above lateral dark structures, while chitinous curves, through which insemination ducts run visible on both sides of epigyne (Fig. 4A). Two chitinous narrow, horn-like apophyses protrude from inner sides of dark chitinuos vulval structures, in apical direction, to empty middle part of vulva (Fig. 5C). Measurements: PL: 1,666; PW: 1,414; OL: 2,609; OW: 1,872; TL = 4,275. Leg formula: $\mathrm{I}>\mathrm{IV}>\mathrm{II}>$ III.

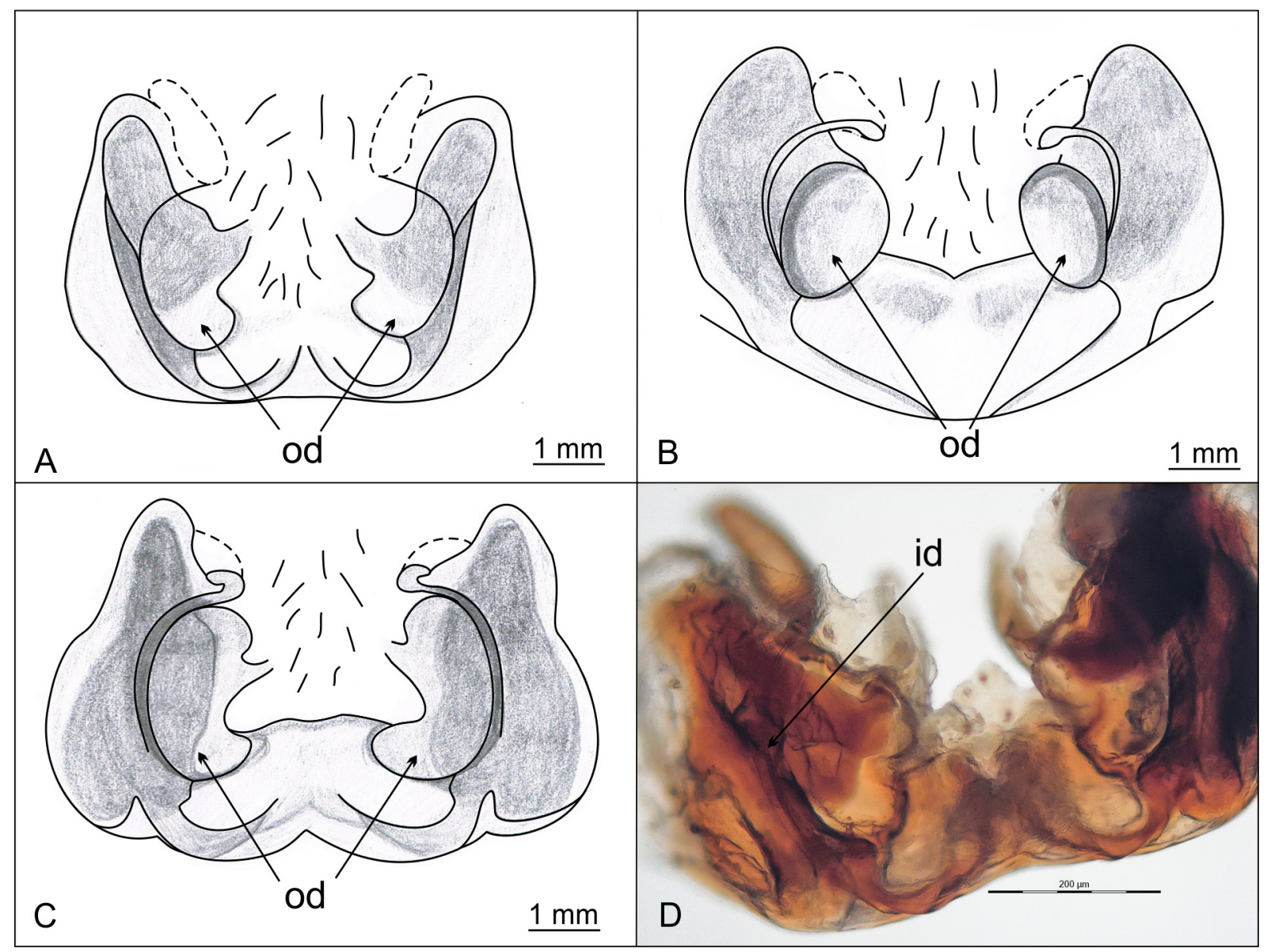

Fig 4. Epigyne and vulva. A. Kryptonesticus deelemanae gen. et sp. nov., epigyne. B. K. fagei (Kratochvíl, 1933), epigyne. C. K. arenstorffi (Kulczyński, 1914), epigyne. D. K. deelemanae gen. et sp. nov. vulva. Broken lines mark the positions of the spermathecae. 
PAVLEK M. \& RIBERA C., A new genus and species of Nesticidae

\begin{tabular}{ccccccccc}
\hline Leg & coxa & troch. & femur & patella & tibia & meta. & tarsus & total \\
\hline I & 0.26 & 0.18 & 4.09 & 0.72 & 4.15 & 3.79 & 1.45 & 14.64 \\
II & 0.19 & 0.15 & 3.14 & 0.63 & 2.81 & 2.58 & 1.18 & 10.69 \\
III & 0.17 & 0.14 & 2.44 & 0.54 & 1.68 & 1.88 & 0.90 & 7.74 \\
IV & 0.18 & 0.16 & 3.52 & 0.64 & 2.76 & 2.70 & 1.08 & 11.04 \\
\hline
\end{tabular}
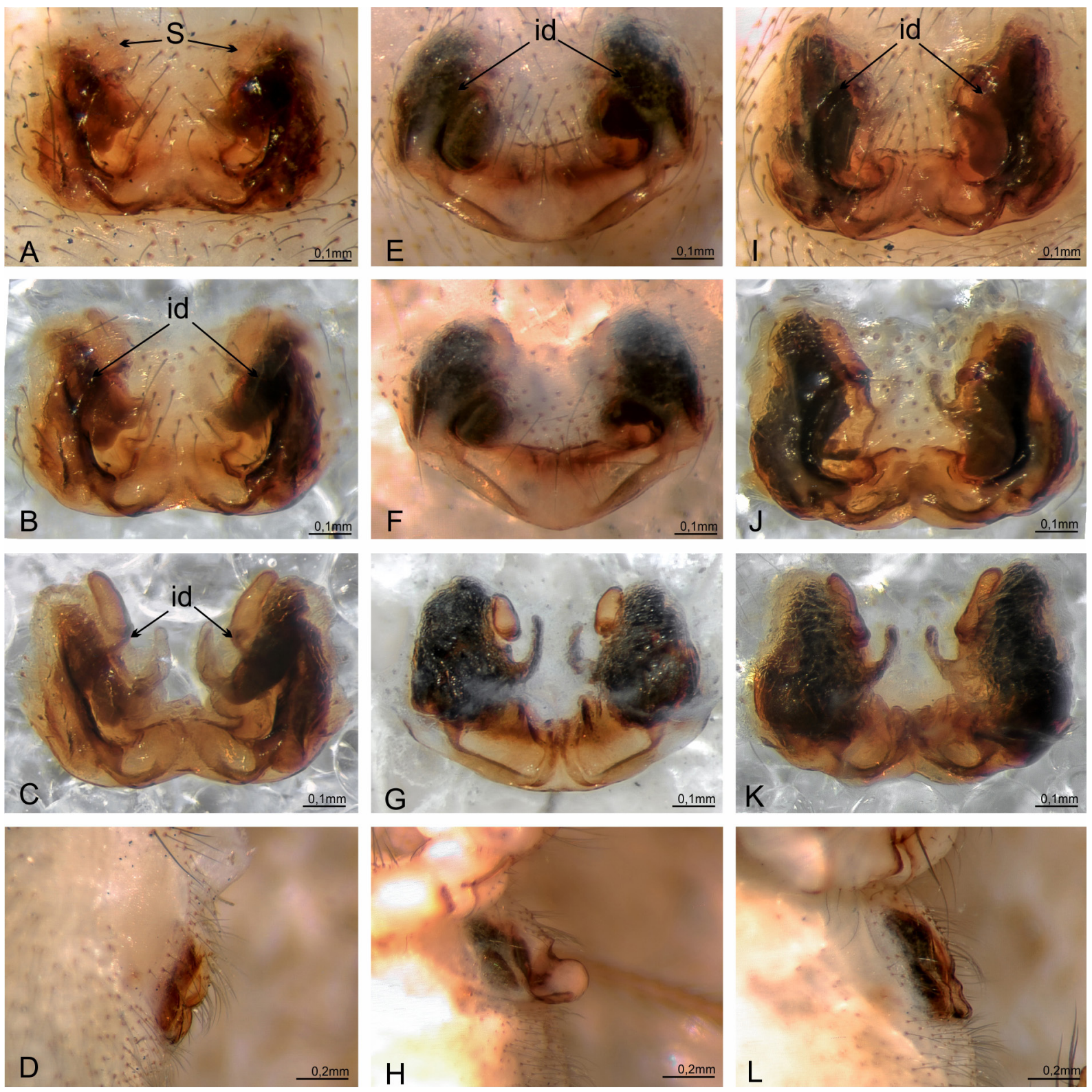

Fig 5. Epigyne and vulva. A-D. Kryptonesticus deelemanae gen. et sp. nov. E-H. K. fagei (Kratochvíl, 1933). I-L. K. arenstorffi (Kulczyński, 1914). A, E, I. Epigyne in ventral view. B, F, J. Epigyne in ventral view after detachment from the opisthosoma. C, G, K. Vulva after treatment with $30 \% \mathrm{KOH}$. D, H, L. Epigyne in lateral view. 


\section{Distribution}

The new species is endemic to Croatia; it is distributed on Biokovo Mt in central Dalmatia, a coastal region in Croatia. So far it has been recorded in 20 caves scattered through the whole mountain, from the south-west sea side to the north-east continental side, from the 310 to 1640 asl (Fig. 6A). Data on all records of $K$. deelemanae gen. et sp. nov. are given in Appendix 2. The distribution area of $K$. deelemanae gen. et sp. nov. is more than $80 \mathrm{~km}$ away from that of $K$. fagei and more than $100 \mathrm{~km}$ from that of $K$. arenstorffi (Fig. 6B).

\section{Natural history}

The type locality, Samogorska špilja, is a small cave with two entrances (Fig. 7). On the date of the last collection, 23 Jan. 2016 , the air temperature in the cave was $0.5^{\circ} \mathrm{C}$ with cold air streaming through the cave, mostly near the cave floor. Spiders were found freely walking on the ceiling of the chamber (probably avoiding the cold air flow at the bottom) and on the side walls of the cave. The temperature in other caves where $K$. deelemanae gen. et sp. nov. is found ranges from 0 to $15^{\circ} \mathrm{C}$. Some of those caves are very small and are greatly influenced by outside conditions (like the type locality), while the others are quite big, have a true cave microclimate and harbor diverse types of cave habitats (for example Pretnerova jama, a 254-meter deep pit). No other nesticid species are found in caves on Biokovo Mt.

\section{Kryptonesticus fagei (Kratochvíl, 1933) comb. nov.}

Figs 2B, 3D-F, 4B, 5E-H

Nesticus fagei Kratochvíl, 1933: 44, 64, pl. 1, fig 4, pl. 2, fig 22, pl. 4, figs 37-40.

Nesticus fagei-Gasparo \& Thaler 2000: 32, figs 3-4. — Le Peru 2011: 364, fig. 630.

Ivesia fagei - Lehtinen \& Saaristo 1980: 51.
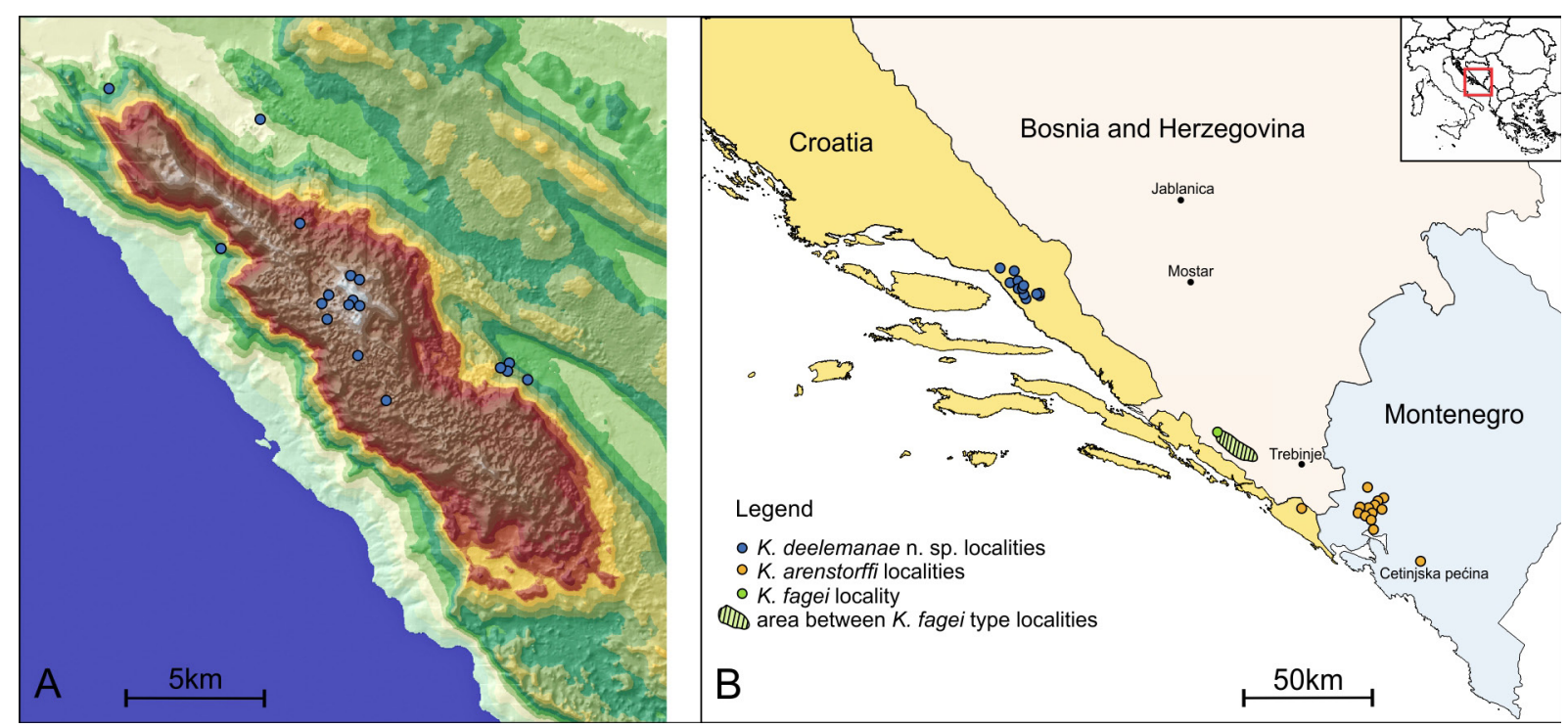

Fig 6. Distribution maps. A. Map of Biokovo Mt with distribution of Kryptonesticus deelemanae gen. et sp. nov. B. Map with distributions of $K$. deelemanae gen. et sp. nov., K. fagei (Kratochvíl, 1933) and K. arenstorffi (Kulczyński, 1914). Marked is the town of Trebinje, near the type locality for $K$. arenstorffi, and also the towns of Mostar and Jablanica, between which is Čudna jama, a dubious record for $K$. arenstorffi. Also marked is Cetinjska pećina, the southernmost locality for $K$. arenstorffi. 


\section{Diagnosis}

Proximal part of MA without process on outer edge, inner side of distal part of MA straight, curve between proximal and distal parts of MA equally rounded. Tegulum with longitudinal ridge stretching through entire surface, basal apophysis of tegulum triangular. Apical branch of dorsal paracymbium process curved in "S" shape, dorsomedian apophysis absent. Epigyne triangular in ventral view, protruding in lateral view. Spermathecae not reaching over vulvar lateral chitinous structures.

\section{Type material}

Not examined. The exact position of the type localities is not known and the surrounding area is at the moment inaccessible (for details see Distribution).

\section{Material examined}

BOSNIA AND HERZEGOVINA: Popovo polje, Bjelušica: 1 ô (CBSS/AR 3701-1), 1 q (CBSS/AR

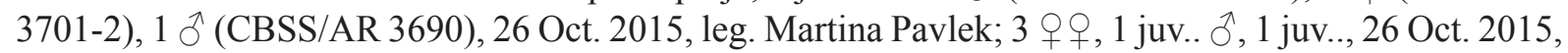

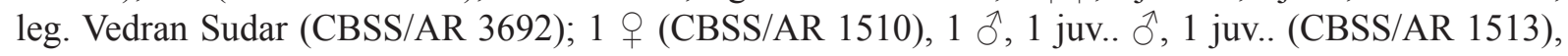
16 Aug. 2004, leg. Roman Ozimec; 1 q, 4 Jun. 2014, leg. Martina Pavlek (CBSS/AR 3389).

\section{Redescription}

\section{Male (CBSS/AR 3701-1)}

Paracymbium with a well-developed dorsal and simple ventral process. Basal branch of dorsal process with straight upper rim, distal part longer and less sharp than in $K$. deelemanae gen. et sp. nov., more pronounced. Apical branch slender, curved in "S" shape, distal part acuminated and sharp (Figs 2B, 3E). Ventral process larger than in $K$. deelemanae gen. et sp. nov., broad and round, most of its surface transparent and with small membranous extension on rim. Dorsomedial apophysis absent (Fig. 3D). Tegulum with longitudinal ridge (in apical view) stretching through entire surface and reaching broad-based triangular basal apophysis (Figs 2B, 3F). Median apophysis well developed, V-shaped, distal arm reaching almost to the apical part of tegulum. Outer edge between proximal and distal part equally rounded, distal part of MA

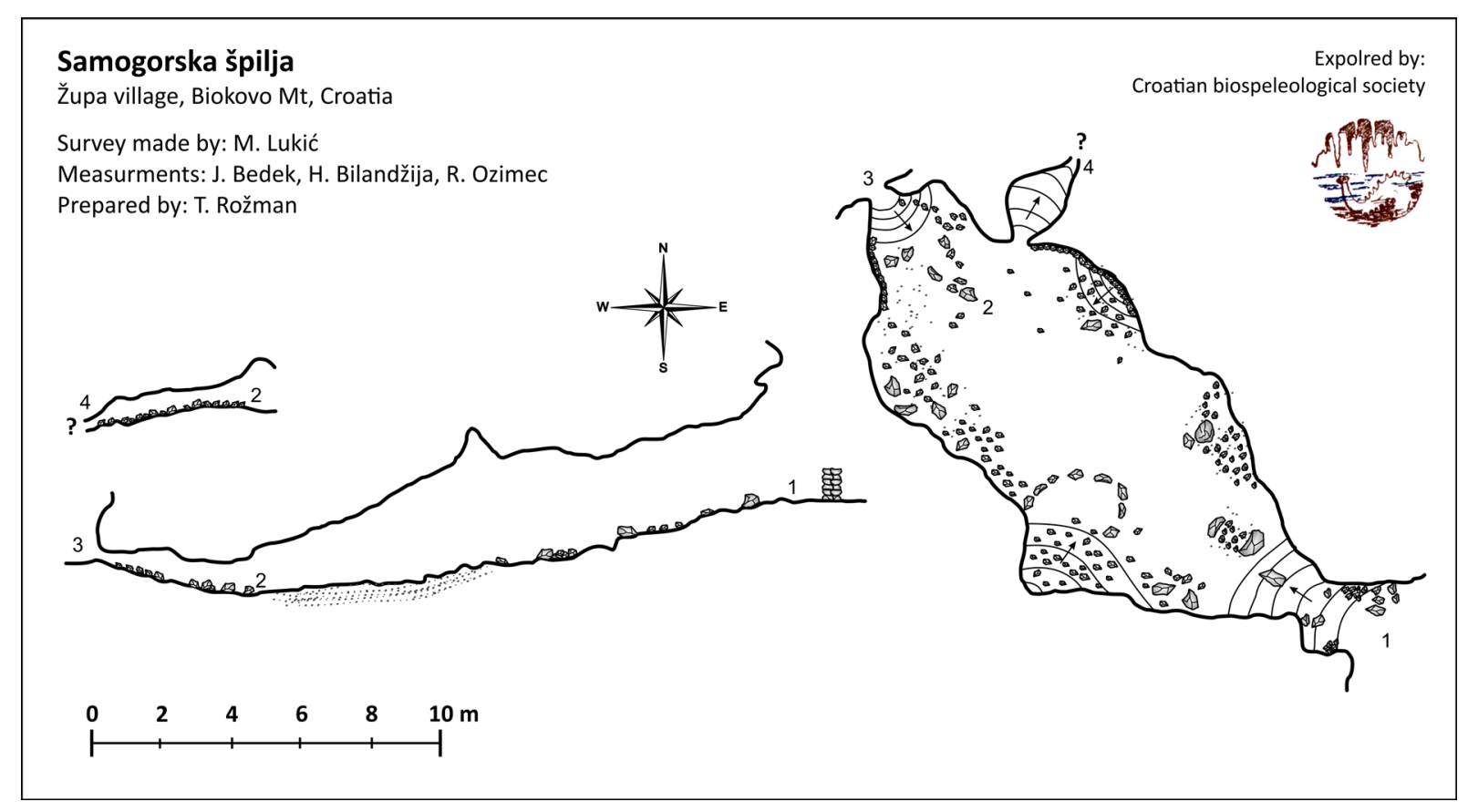

Fig 7. A survey of the K. deelemanae gen. et sp. nov. type locality: Samogorska špilja. 
narrowing toward top, which ends bluntly with slightly serrated upper edge. Inner side of distal part of MA straight. Embolus, TTA p1 and TTA p2 of TTA similar to in $K$. deelemanae gen. et sp. nov. (Figs 2B, 3D).

Female (CBSS/AR 3701-2)

EPIGYNE. Slightly wider than long. Lateral lobes with oval depressions in posterior part, reaching middle of epigyne. Posterior epigyne border triangular in ventral view, made of two straight chitinous arches which flank depressions, come together in middle and after sharp inward turn form broad and pale convex tubercle (Figs 4B, 5E-F), protruding in lateral view (Fig. 5H). Insemination ducts visible on both sides of epigyne in a form of chitinous curves (Figs 4B, 5E-F).

VULVA. Lateral sides of vulva made of compact dark chitinous structures enclosed in firm transparent membrane (lateral pouches). Spermathecae oval-shaped, with shallow constriction in middle, narrower in upper part and less slender then in K. deelemanae gen. et sp. nov., located meso-apicaly behind dark chitinous lateral structures. Insemination ducts depart from bottom of spermathecae, make sharp turn outwards and continue to epigynal base. Two chitinous narrow, horn-like structures protrude from inner sides of dark chitinuos vulval structures, in apical direction, to empty middle part of vulva (Fig. 5G).

\section{Distribution}

This species was described based on the material collected by Kratochvíl in several caves in Herzegovina, on the north-west border of Popovo polje: Pećina kod Tamnicam and Jama za Jamskim vrhom near Belenići village and Pčelina pećina near Nevada village (Kratochvíl 1933). The type material is deposited in the National Museum in Prague (Ružička et al. 2005). The area where the type localities are is inaccessible at the moment because of the mine fields left after the civil war in Bosnia and Herzegovina in the 1990s. The species is known from only one more locality, Bjelušica (Dresco 1966; Kratochvíl 1936), a horizontal cave around $4 \mathrm{~km}$ north of Belenići village (Fig. 6B). The material for this redescription was collected there. The species is endemic for Bosnia and Herzegovina and the citation of 'Montenegro' in 'The Spiders of Europe' (Nentwig et al. 2016) is erroneous.

\section{Natural history}

Bjelušica is a small cave, around $150 \mathrm{~m}$ long. From the semi-dark entrance chamber departs a narrowing, $1 \times 2$ meters wide passage that leads to the main channel which, after the first few meters that are slightly lighter, is always in complete darkenss. The spiders were found right after the narrowing and all along the cave. They were mostly hanging from their nets on the walls and between the big stones on the cave floor, or freely walking on the walls of the cave. The temperature in the cave is around $13.5^{\circ} \mathrm{C}$. In his paper with the description of $K$. fagei (Kratochvíl 1933), Kratochvíl also listed K. eremita at one of the type localities, Jama za Jamskim vrhom. Since it is not common for two species of the same genus to inhabit the same cave, we wanted to check the original material, but that was unfortunately impossible since the specimens deposited in the museum in Prague are without pedipalps (personal communication with Petr Dolejš, curator of the spider collection). In the last 20 years, researchers from CBSS have visited many caves around the town of Trebinje, in the Popovo polje area, and in the hilly region between Popovo polje and Croatia, but have so far recovered no K. eremita.

Kryptonesticus arenstorffi (Kulczyński, 1914) comb. nov. Figs 2C, 3G-I, 4C, 5I-L

Nesticus arenstorffi Kulczyński, 1914: 378, pl. 16, fig. 50.

Nesticus arenstorffi - Kratochvíl 1933: 42, 64, pl. 1, fig. 5, pl. 4, figs 34-36. — Le Peru 2011: 361, fig. 620. Ivesia arenstorff - Lehtinen \& Saaristo 1980: 51. 


\section{Diagnosis}

Proximal part of MA without process on outer edge, inner side of distal part of MA with bulge in middle, edge between proximal and distal part of MA pointed. Tegulum with triangular basal apophysis. Dorsomedian apophysis of paracymbium absent. Posterior epigyne outline wavy, ridge apically bordering lateral depressions well visible. Spermathecae not reaching over vulvar lateral chitinous structures.

\section{Type material}

Not examined. The exact position of the type locality is unknown (for details see Distribution).

\section{Material examined}

MONTENEGRO: 1 ○ (CBSS/AR 3288-1), 1 \& (CBSS/AR 3288-2), Kotorski zaljev, Golodražnica, 31

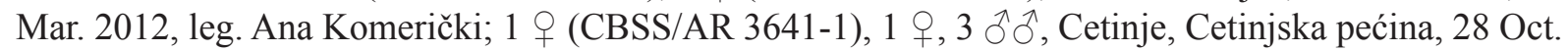
2015, leg. Martina Pavlek (CBSS/AR 3641-2).

\section{Redescription}

Male (CBSS/AR 3288-1)

Paracymbium with well-developed dorsal and simple ventral process. Basal branch of dorsal process with slightly convex upper rim which ends in the shape of an indistinct minor blunt tooth. Longer apical branch similar to that in $K$. deelemenae gen. et sp. nov. but more robust, dilated in middle and attenuated towards top (Figs 2D, 3H). Ventral process broad and round, with transparent middle part and no membranous extension on rim. Dorsomedial apophysis absent (Fig. 3G). Tegulum with inconspicuous groove, low round swelling in apical part (Fig. 2B, in apical view in Fig. 3I), and with triangular broadbased basal apophysis. Median apophysis well developed, V-shaped, distal arm reaching almost to apical part of tegulum. Outer edge between proximal and distal part pointed, not equally rounded as in $K$. deelemanae gen. et sp. nov. and $K$. fagei. Distal part of MA narrowing toward top; top bluntly ended with serrated upper edge. Inner side of distal part of MA with bulge in middle. Embolus, TTA p1 and TTA p2 of TTA similar to those in K. deelemanae gen. et sp. nov. (Figs 2D, 3G).

\section{Female (CBSS/AR 3641-1)}

EpIGYNe. Slightly wider than long. In lateral view not protruding very much (Fig. 5L). Lateral lobes with oval depressions in posterior part, reaching middle of epigyne. Posterior epigyne border made of two semicircular chitinous arches, flanking depressions and coming together in middle, forming a small, pale, inconspicuous convex tubercule. Ridge apically bordering tubercle well visible. Epigyne outline, laterally of semicircular chitinous arches, with shallow notches. In ventral view, chitinous curves through which insemination ducts extend visible on both sides of epigyne (Figs 4C, 5I-J).

Vulva. Lateral sides of vulva made of compact dark chitinous structures enclosed in firm transparent membrane (lateral pouches). Spermathecae slender, oval-shaped, with shallow constriction in middle, located meso-apically behind dark chitinous lateral structures. Insemination ducts depart at bottom and extend to epigynal base. Two chitinous narrow, horn-like structures protrude from inner sides of dark chitinous lateral structures, in apical direction, to empty middle part of vulva (Fig. 5K).

\section{Distribution}

The type locality is Laketićeva pećina near the town of Trebinje in Bosnia and Herzegovina (Kulczyński 1914). Since the original description, it has not been collected at the type locality and its exact position is at the moment unknown. In the surroundings of the town of Trebinje no cave with such a name is known. The type material is deposited in the National Museum in Prague (Ružička et al. 2005). The species is also known from Čudna jama near Mostar (Fage 1931) and from 19 more caves in Montenegro (Kratochvíl 1933, 1935; Deeleman-Reinhold 1974). Recently, the species has been recorded in three 
more caves: Cetinjska pećina as reported by Deltshev et al. (2014) and personal observations, Pećina Vojvode Dakovića (pers. obs.) in Montenegro, and from cave Jezero on Sniježnica Mt which is the first record for Croatia (all records from the CBSS collection are listed in Appendix 3). All localities are marked on the map in Fig. 6B. In the last 20 years, researchers from CBSS visited many caves around the town of Trebinje, in the Popovo polje region and in other parts of Bosnia and Herzegovina, but recovered no $K$. arenstorffi. Čudna jama near Mostar is far away from all certain $K$. arenstorff localities and we wanted to check that material, deposited in the National Museum in Prague, but unfortunately there are only two subadult males and a juv.enile inside the vial (personal communication with Petr Dolejš, curator of the spider collection) so the taxonomical status of the samples could not be confirmed. We consider that locality dubious. The citation of Serbia in 'The Spiders of Europe' (Nentwig et al. 2016) is erroneous.

\section{Natural history}

$K$. arensorff $\mathrm{specimens}$ were mostly found hanging upside down from the webs, in the entrance part but also deeper in the caves. The temperature in the caves where $K$. arenstorffi has recently been collected ranges between $5^{\circ} \mathrm{C}$ and $15^{\circ} \mathrm{C}$. Generally, in all caves where $K$. arenstorffi was recorded no other nesticid species was present, except in Cetinjska pećina in the town of Cetinje in Montenegro. This cave is inhabited by the troglobiotic species Typhlonesticus absoloni as reported by Christa Deeleman-Reinhold (1974), and it has also been collected recently (Appendix 4). It is worth noting that in her 1974 paper, Christa Deeleman-Reinhold did not mention the presence of $K$. arenstorffi. Her collecting trip was in 1972, before Cetinjska pećina was adapted for touristic visits and before a tunnel was dug into the cave from the outside (in the 1980s). The tunnel has surely changed the microclimatic conditions in the cave by introducing a constant air flow, so it could have made some parts of the cave less suitable for the troglobiotic Typhlonesticus absoloni (found only in deeper parts), but more accommodating for the less troglomorphic K. arenstorffi.

\section{Molecular data}

Specimens, localities and sequences with corresponding GenBank accession numbers analyzed in the present study are listed in Appendix 1. The concatenated matrix used in phylogenetic analyses includes 12 terminals and 1699 aligned characters $(\operatorname{coxl}=931, r r n=451$ and $H 3=317)$. Primer fidelity across taxa was not always consistent in coxl, which is why some specimens have slightly truncated sequence lengths. The preferred partitioning scheme included three partitions: the first and second position of the coxl and $H 3$ gene fragments; the third codon position of coxl and H3; and rrnL. Uncorrected coxl pairwise (p)-distances among terminal taxa and within and between genera are summarized in Appendix 5.

Fig. 8 shows the ML tree inferred using the combined data matrix. Kryptonesticus, Nesticus and Carpathonesticus show high bootstrap support (81, 90 and 100 respectively). Among representatives of Kryptonesticus, the new species clusters with $K$. arenstorff $i$ and $K$. fagei, the geographically closest species, with a low bootstrap value. The remaining three species $(K$. henderickxi, $K$. eremita and $K$. dimensis) are poorly supported (low bootstrap support) and do not allow us to determine its internal relationships. $N$. cellulanus, the type species of the genus Nesticus, is the sister species of the representatives of Carpathonesticus included in this analysis.

The topologies of the partial analyses of the three genes separately were almost identical at the genus level and no inconsistencies were detected. In coxl and rrn, $N$. cellulanus is the sister species of the Carpathonesticus evolutionary line, while Kryptonesticus gen. nov. is the sister group of the clade formed by Nesticus and Carpathonesticus. In $\mathrm{H3}$ partial sequences, these three evolutionary lines are 
also present ( $N$. cellulanus, Kryptonesticus and Carpathonesticus) but forming a polytomy at the generic level.

Within the Kryptonesticus clade, only $H 3$ shows good bootstrap support for $K$. fagei, $K$. arenstorffi and $K$. deelemanae gen. et sp. nov. (90\%), while with $r r n L$ only $K$. deelemanae gen. et sp. nov. and $K$. arenstorffi show bootstrap support, although very low (59\%), while with coxl no support exists for these species.

The mean uncorrected p-distances of coxl between and within taxa analyzed (Appendix 5) show high values. The mean p-distance between genera ranges from 17.5\% (Typhlonesticus vs Carpathonesticus) to $10.9 \%$ (Nesticus vs Carpathonesticus). The genetic divergences between Kryptonesticus gen. nov. and Typhlonesticus, Carpathonesticus and Nesticus are 16.6, 11.7 and 12.1\%, respectively. The average evolutionary divergence between representatives within the new genus is $8.2 \%(6.2 \%$ among the three species from Dinarides).

\section{Discussion}

This paper describes a new genus belonging to the Nesticidae. The molecular phylogenetic analysis includes the type species of the genera Nesticus, Carpathonesticus and Thyphlonesticus, all from the Mediterranean Basin. It indicates that Nesticus cellulanus, the type species of Nesticus, is sister to a

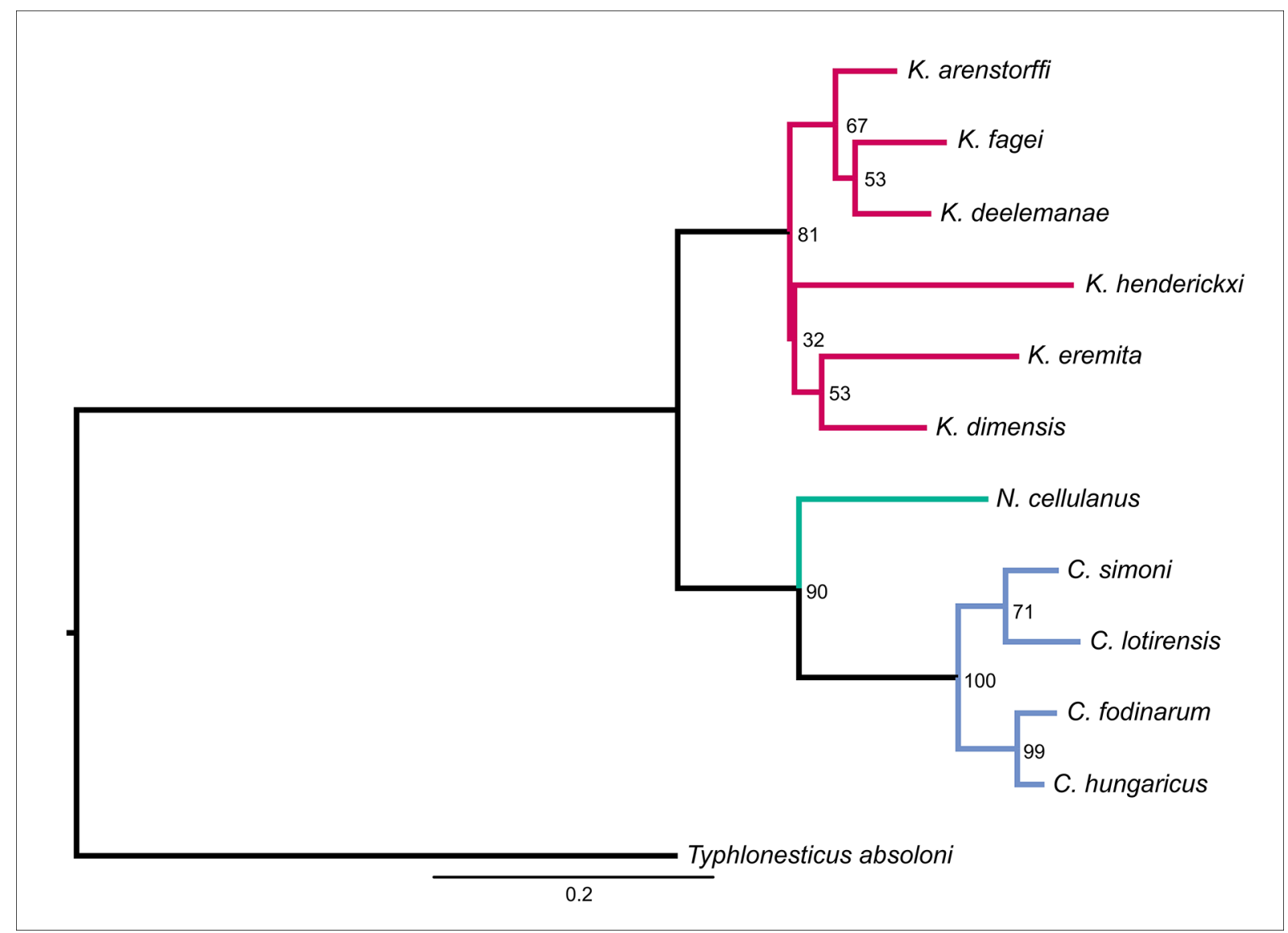

Fig 8. ML tree inferred from a concatenated matrix of cox 1 and $r r n$ mtDNA and $H 3$ nuDNA gene fragments. Numbers next to nodes correspond to bootstrap support values. The tree was rooted using Typhlonesticus absoloni (Kratochvíl, 1933). 
group containing all the species of Carpathonesticus included in the analysis (bootstrap support 90\%), including the type species. The new genus constitutes a well-defined and independent evolutionary lineage with a high bootstrap support and shows mean uncorrected p-distances of coxl of 11.7 versus Carpathonesticus and 12.1 versus Nesticus cellulanus. Typhlonesticus is clearly more distanced (16.6). From a morphological point of view, Kryptonesticus gen. et sp. nov. is also well defined. The large size and the shape of the median apophysis in males, and the shape and position of spermathecae and insemination ducts in females, constitute the main diagnostic characteristics. This is in accordance with Kratochvíl's Dinaric group, in which he placed $K$. fagei and $K$. arenstorffi (Kratochvíl 1933), the only species now referred to Kryptonesticus gen. nov. known at that time. It does not include $K$. eremita which is morphologically the most aberrant within the genus. Accordingly, we propose the following new combinations:

Kryptonesticus eremita (Simon, 1879) comb. nov. (ex Nesticus eremita Simon, 1880: 258)

Kryptonesticus arenstorffi (Kulczyński, 1914) comb. nov. (ex Nesticus arenstorffi Kulczyński, 1914: 378)

Kryptonesticus fagei (Kratochvíl, 1933) comb. nov. (ex Nesticus fagei Kratochvíl, 1933: 44)

Kryptonesticus beroni (Deltshev, 1977) comb. nov. (ex Nesticus beroni Deltshev, 1977: 75)

Kryptonesticus beshkovi (Deltshev, 1979) comb. nov. (ex Nesticus beshkovi Deltshev, 1979: 53)

Kryptonesticus henderickxi (Bosselaers, 1998) comb. nov. (ex Nesticus henderickxi Bosselaers, 1998: 9)

Kryptonesticus dimensis (López-Pancorbo, Kunt \& Ribera, 2013) comb. nov. (ex Nesticus dimensis López-Pancorbo et al., 2013: 185)

The presence of "pipette setae" (Grall \& Jäger 2016) in males of Kryptonesticus gen. nov. supports the proposition that it is a potential new diagnostic character for Nesticidae (we can also confirm its presence in males of Typhlonesticus absoloni).

There is great confusion about the identity of $N$. speluncarum Pavesi, 1873, an endemic species from northern Italy. Several authors have considered it a subspecies of $N$. eremita (Simon 1929; Kratochvíl 1934); however, the drawings of the male palp (not the female) of this species clearly separate it from other known species (Brignoli 1971; Caporiacco 1934; Dresco 1966). Its distribution is also not clear, although quite restricted. In our last two papers on nesticids (López-Pancorbo et al. 2013; Ribera et al. 2014) we included partial sequences of coxl and $H 3$ (GenBank accession numbers KF417421 and KF417405) from $N$. speluncarum. After a revision of the material identified, we noticed an error in the identification of this species. It is not $N$. speluncarum, but $K$. eremita, and for that reason it has not been included in this work.

A very special trait of several species of this new genus ( $K$. beroni from Bulgaria, $K$. beshkovi and $K$. henderickxi from Crete, and $K$. dimensis from Turkey) is their possession of highly troglomorphic characteristics, such as the absence of, or very reduced, eyes (size and number), and the lack of body pigmentation. In addition, these species are known from a single or a small number of caves. These data suggest that these species are probably very sensitive to disturbances in their environment and are thus clear candidates for protection: they have highly restricted ranges and show a high degree of adaptation to the subterranean environment.

\section{Acknowledgments}

We express our warmest gratitude to Christo Deltshev, Alberto Lopez-Pancorbo, Marko Lukić, Tin Rožman, Vedran Sudar, Roman Ozimec, Ana Komerički and Jan Bosselaers for collecting and sending the material, photos and information on the localities, and to all other collectors and Anđela Ćukušić for initial checks of the spider material from Biokovo caves. Thanks to the numerous speleologists for their help in field trips and collecting, and especially the members of CBSS. Thanks to Tin Rožman for help in adjusting drawings, photos, to Marko Lukić for help in making the distribution maps, to Dr. Sc. Josip 
PAVLEK M. \& RIBERA C., A new genus and species of Nesticidae

Balabanić for advice on the Latin name of the new species and to Nevenka Meštrović Radan, a mentor of the ESF project. Also thanks to Miguel A. Arnedo for using the lupa, Marcos Roca-Cusachs for help with drawing and Humbert Salvadó for using the microscope. Thanks to Lida Lamza and Rebecca J. Wilson for English check.

This research was supported by grants CGL2004-05771 and CGL2006-13374/BOS (Ministerio de Educación y Ciencia, Spain), by the European Union's Human Resources Development Operational Programme under grant agreement HR.3.2.01-0015 (ESF project) and by Biokovo Nature Park.

\section{References}

Bosselaers J. 1998. Nesticus henderickxi (Araneae, Nesticidae), a new blind troglobitic spider from Crete. Bulletin of the British Arachnological Society 11: 9-14.

Brignoli P.M. 1971. Note sui ragni cavernicoli italiani. Fragmenta Entomologica 7: 121-229.

Caporiacco L. di. 1934. I Nesticus liguri ed emiliani. Annali del Museo Civico di Storia Naturale di Genova 56: 395-405.

Deeleman-Reinhold C.L. 1974. The cave spider fauna of Montenegro (Araneae). Glasnik Republičkog Zavoda za Zaštitu Prirode i Prirodnjačkog Muzeja 6: 9-33.

Deltshev C. 1977. Genus Nesticus (Nesticidae, Araneae) from Bulgarian caves. Congrès international de Spéléologie 6 (Olomouc, 1973): 73-78.

Deltshev C. D. 1979. A contribution to the study of cave spiders (Araneae) in Greece. Four new species (Araneae, Nesticidae, Linyphiidae) from the islands of Crete and Thera. Acta Zoologica Bulgarica 13: 53-63.

Deltshev C., Ćurčić B., Wang C., Yao Z., Antić D., Ćurčić S. \& Rada T. 2014. New data on the spiders (Araneae) in the caves of Balkan Peninsula. Archives of Biological Sciences 66: 465-472. http://dx.doi. org/10.2298/ABS1402465D

Dresco E. 1966. Étude de quelques espèces d'araignées du genre Nesticus (Fam. Nesticidae). Annales de Spéléologie 21: 795-813.

Fage L. 1931. Araneae cinquième série, précédée d'un essai sur l'évolution souterraine et son déterminisme. Archives de Zoologie expérimentale et générale, Biospeologica LV 71: 99-291.

Gasparo F. \& Thaler K. 2000. I ragni cavernicoli della Venezia Giulia (Italia nord-orientale) (Arachnida, Araneae). Atti e Memorie, Comm. Grotte "Eugenio Boegan" 37: 17-55.

Grall E. \& Jäger P. 2016. Four new species of the spider genus Nesticella Lehtinen \& Saaristo, 1980 from Laos, Thailand and Myanmar and the first description of the male of Nesticella yui Wunderlich \& Song, 1995 with a proposed new diagnostic character for the family Nesticidae Simon, 1894. Zootaxa 4085: 248-264. http://dx.doi.org/10.11646/zootaxa.4085.2.5

Huber B.A. 1993. Genital mechanics and sexual selection in the spider Nesticus-cellulanus (Araneae, Nesticidae). Canadian Journal of Zoology 71: 2437-2447. http://dx.doi.org/10.1139/z93-340

Katoh K. \& Toh H. 2008. Improved accuracy of multiple ncRNA alignment by incorporating structural information into a MAFFT-based framework. BMC Bioinformatics 9: e212. http://dx.doi. org/10.1186/1471-2105-9-212

Kearse M., Moir R., Wilson A., Stones-Havas S., Cheung M., Sturrock S., Buxton S., Cooper A., Markowitz S., Duran C., Thierer T., Ashton B., Mentjies P. \& Drummond A. 2012. Geneious Basic: an integrated and extendable desktop software platform for the organization and analysis of sequence data. Bioinformatics 28 (12): 1647-1649. http://dx.doi.org/10.1093/bioinformatics/bts199 
Kratochvíl J. 1933. Evropské druhy celedi Nesticidae Dahl. Práce Moravské Přirodovědecké Společnosti 8: $1-69$.

Kratochvíl J. 1934. Pregled pećinskih paukova u Jugoslaviji. Prirodoslovne Razprave 2: 165-226.

Kratochvíl J. 1935. Araignées cavernicoles de Krivošije. Práce Moravské Přirodovědecké Společnosti 9: $1-25$.

Kratochvíl J. 1936. Nouveau genre d'araignées cavernicoles en Yugoslavie. Typhlonyphia reimoseri n. gen. n. sp. Vestnik Československe Zoologicke Společnosti 3: 69-79.

Kratochvíl J. 1978. Araignees cavernicoles des iles dalmates. Přirodovědné práce ústavi Československé Akademie Věd v Brnè (N.S.) 12 (4): 1-59.

Kulczyński W. 1914. Aranearum species novae minusve cognate in montibus Kras dictis a Dre C. Absolon aliisque colectae. Bulletin international de l'Académie des Sciences de Cracovie 13: 353-387. Available from http://biodiversitylibrary.org/page/4553795 [accessed 17 Jan. 2017].

Kumar S., Stecher G. \& Tamura K. 2016. MEGA7: Molecular Evolutionary Genetics Analysis version 7.0 for bigger datasets. Molecular Biology and Evolution 33: 1870-1874. http://dx.doi.org/10.1093/ molbev/msw054

Lanfear R., Calcott B., Ho S.Y.W. \& Guindon S. 2012. PartitionFinder: Combined selection of partitioning schemes and substitution models for phylogenetic analyses. Molecular Biology and Evolution 29: 1695-1701. http://dx.doi.org/10.1093/molbev/mss020

Lehtinen P.T. \& Saaristo M.I. 1980. Spiders of the Oriental-Australian region. II. Nesticidae. Annales Zoologici Fennici 17: 47-66.

Le Peru B. 2011. The Spiders of Europe, a synthesis of data. Volume 1 Atypidae to Theridiidae. Mémoires de la Société linnéenne de Lyon 2: 1-522.

López-Pancorbo A., Kunt K.B., Blagoev G., Deltshev C. \& Ribera C. 2013. Nesticus dimensis new species, a new troglobitic spider from Turkey (Araneae, Nesticidae), with comments on its phylogenetic relationships. Zootaxa 3721: 183-192. http://dx.doi.org/10.11646/zootaxa.3721.2.5

López-Pancorbo A. \& Ribera C. 2011. Nesticus baeticus sp. n., a new troglobitic spider species from south-west Europe (Araneae, Nesticidae). ZooKeys 89: 1-13. http://dx.doi.org/10.3897/zookeys.89.921

Nentwig W., Blick T., Gloor D., Hänggi A. \& Kropf C. 2016. Spiders of Europe. Version 02 [online]. Available from http://www.araneae.unibe.ch/

Ozimec R. \& Jalzic B. 1999. Cave dweling fauna of Mt. Biokovo, M. Dalmatia, Croatia. In: Abstracts of the $14^{\text {th }}$ International Symposium of Biospeleology, Makarska. Hrvatsko biospeleološko društvo, Hrvatski prirodoslovni muzej, Zagreb, $125 \mathrm{pp}$.

Ribera C., Elverici M., Boğaç Kunt K. \& Sulhi Özkütük R. 2014. Typhlonesticus gocmeni sp. n., a new cave-dwelling blind spider species from the Aegean region of Turkey (Araneae, Nesticidae). ZooKeys 419: 87-102. http://dx.doi.org/10.3897/zookeys.419.5739

Ružička V., Kurka A., Buchar J. \& Řezáč M. 2005. Czech Republic - the type material of spiders (Araneae). Časopis Národního muzea, Řada př́rodovédná 174: 13-64.

Silvestro D. \& Michalak I. 2012. raxmlGUI: A graphical front-end for RAxML. Organisms Diversity and Evolution 12: 335-337. http://dx.doi.org/10.1007/s13127-011-0056-0

Simon E. 1880. Arachnides nouveau de France, d'Espagne et d'Algérie. Premier mémoire. Bulletin de la Société zoologique de France 4: 251-263. 
Simon E.L. 1929. Les Arachnides de France. Synopsis générale et Catalogue des Espèces françaises de l'Ordre des Araneae. 3e partie, 6: 533-772. Paris.

Stamatakis A. 2006. rAxML-VI-HPC: Maximum likelihood-based phylogenetic analyses with thousands of taxa and mixed models. Bioinformatics 22: 2688-2690. http://dx.doi.org/10.1093/bioinformatics/ $\underline{\text { bt1446 }}$

Vink C.J. \& Dupérré N. 2011. Nesticus eremita (Araneae: Nesticidae): redescription of a potentially invasive European spider found in New Zealand. Journal of Arachnology 39: 511-514. http://dx.doi. org/10.1636/a11-57.1

World Spider Catalog. 2016. Natural History Museum Bern, version 17.0. Available from http://wsc. nmbe.ch [accessed Apr. 2016].

Manuscript received: 12 May 2016

Manuscript accepted: 4 August 2016

Published on: 20 January 2017

Topic editor: Rudy Jocqué

Desk editors: Laurence Bénichou \& Danny Eibye-Jacobsen

Printed versions of all papers are also deposited in the libraries of the institutes that are members of the EJT consortium: Muséum national d'Histoire naturelle, Paris, France; Botanic Garden Meise, Belgium; Royal Museum for Central Africa, Tervuren, Belgium; Natural History Museum, London, United Kingdom; Royal Belgian Institute of Natural Sciences, Brussels, Belgium; Natural History Museum of Denmark, Copenhagen, Denmark; Naturalis Biodiversity Center, Leiden, the Netherlands. 
Appendix 1. Specimens, localities and sequences with corresponding GenBank accession numbers analyzed in the present study (sequences with * are new for this study).

\begin{tabular}{|c|c|c|c|c|}
\hline Species & Locality & Coxl & $r m L$ & $H 3$ \\
\hline $\begin{array}{l}\text { K. deelemanae } \\
\text { gen. et sp. nov. }\end{array}$ & $\begin{array}{c}\text { Samogorska špilja, Biokovo Mt., Croatia }\left(43^{\circ} 19^{\prime} 5,71^{\prime}\right. \\
\left.\text { N, } 17^{\circ} 7^{\prime} 29,9^{\prime} \text { E, } 717 \mathrm{~m}\right)\end{array}$ & KX632167* & KX632160* & KX611237* \\
\hline K. fagei & $\begin{array}{l}\text { Bjelušica, Popovo polje, Bosnia and Herzegovina } \\
\qquad\left(42^{\circ} 50^{\prime} 41^{\prime \prime} \mathrm{N}, \mathrm{E} 17^{\circ} 58^{\prime} 43^{\prime \prime} \mathrm{E}, 350 \mathrm{~m}\right)\end{array}$ & KX632166* & KX632159* & KX611236* \\
\hline K. arenstorffi & $\begin{array}{l}\text { Čora pećina, Crni nugli, Dragaljsko polje, Gorn- } \\
\text { je Krivošije, Selakov do, Risan Distr., Montenegro } \\
\left(42^{\circ} 35^{\prime} 36,5^{\prime} \text { N, E } 18^{\circ} 41^{\prime} 41,6^{\prime} \text { E, } 750 \mathrm{~m}\right)\end{array}$ & KF417407 & KF417403 & KF417422 \\
\hline K. eremita & $\begin{array}{l}\text { Pišurka (=Paganetijeva pećina), town of Korčula, Korču- } \\
\text { la Isl., Croatia }\left(42^{\circ} 57^{\prime} 33,83^{\prime \prime} \text { N, E } 17^{\circ} 7^{\prime} 45,26^{\prime} \text { E, } 58 \text { m) }\right.\end{array}$ & KX632165* & KF417400 & - \\
\hline K. henderickxi & Kournas Cave, Kournas, Crete & KX632164* & KF417404 & - \\
\hline K. dimensis & $\begin{array}{l}\text { Dim Cave, Taurus Mountains, Alanya District. Turkey } \\
\qquad\left(36^{\circ} 32^{\prime} 337^{\prime \prime} \mathrm{N}, 32^{\circ} 06^{\prime} 599^{\prime} \text { E, } 189 \mathrm{~m}\right)\end{array}$ & KF417406 & KF417401 & KF417420 \\
\hline N. cellulanus & Manantiales Monte Castro, Sueces, Castelló, Spain & KX632163* & EU746444 & KX611235* \\
\hline C. fodinarum & $\begin{array}{c}\text { Pesterea Cave, Poarte lui Joarnele, Giarda, Alba, Garda, } \\
\text { Romania }\end{array}$ & KX632162* & KX632158* & \\
\hline C. lotriensis & 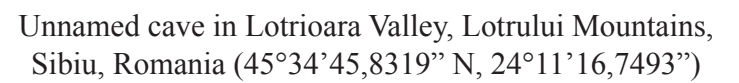 & KX632161* & KF417399 & KF417418 \\
\hline C. hungaricus & $\begin{array}{l}\text { Pestera cave, Liliecilor, Cheile Ampoitei Gorges, Roma- } \\
\text { nia }\left(46^{\circ} 08^{\prime} 21,7748^{\prime \prime} \text { N, } 23^{\circ} 23^{\prime} 39,8507^{\prime \prime}\right)\end{array}$ & KF417412 & KF417402 & KF417419 \\
\hline C. simoni & $\begin{array}{c}\text { Unnamed cave in Bisbrita Gorges, Stogu-Vinturarita } \\
\text { Mts., Romania ( } 45^{\circ} 11^{\prime} 42,2789^{\prime} \text { N, } 24^{\circ} 02^{\prime} 03,2702^{\prime} \text { E, } \\
491 \mathrm{~m})\end{array}$ & KF417408 & KF417398 & KF417417 \\
\hline T. absoloni & $\begin{array}{l}\text { Baba Tuša cave, Trnovo, Virpazar Distr., Montenegro } \\
\left(42^{\circ} 17^{\prime} 25,1^{\prime \prime} \mathrm{N}, 1^{\circ} 02^{\prime} 10,8^{\prime \prime} \mathrm{E}, 350 \mathrm{~m}\right)\end{array}$ & KF417410 & KF417397 & KF417416 \\
\hline
\end{tabular}


Appendix 2. All records of $K$. deelemanae gen. et sp. nov. from the CBSS collection. Date format: dd.mm.yyyy.

\begin{tabular}{|c|c|c|c|c|c|}
\hline $\begin{array}{l}\text { CBSS coll. } \\
\text { number }\end{array}$ & Cave name & Location of the cave & $\begin{array}{l}\text { Collection } \\
\text { date }\end{array}$ & Collector & $\begin{array}{c}\text { Number and } \\
\text { gender of spec- } \\
\text { imes }\end{array}$ \\
\hline AR: 1268 & Kukor & Croatia, Biokovo Mt., Bast village & 8.9 .2005 & Roman Ozimec & 1 우 \\
\hline AR: 1269 & $\begin{array}{l}\text { Ograđena špilja pod Sv. } \\
\text { Jurom }\end{array}$ & Croatia, Biokovo Mt., Sv. Jure & 21.6.2003 & Branko Jalžić & 2 juv. \\
\hline AR: 1271 & Matijaševa peć & Croatia, Biokovo Mt., Župa village & 4.4.2006 & Helena Bilandžija & 1 juv. \\
\hline AR: 1272 & Kukor & Croatia, Biokovo Mt., Bast village & 27.7.2004 & Roman Ozimec & 1 juv. \\
\hline AR: 1273 & Špilja u Radinovcima & $\begin{array}{c}\text { Croatia, Biokovo Mt., Zagvozd, } \\
\text { Rastovac village }\end{array}$ & 25.10 .2006 & Roman Ozimec & $\begin{array}{l}2 q+, 2 \hat{\jmath} \hat{\sigma}, 2 \\
\text { juv. }\end{array}$ \\
\hline AR: 1274 & Poskokova rupa & Croatia, Biokovo Mt., Župa village & 25.5.2004 & Roman Ozimec & 1 우 \\
\hline AR: 1275 & Kukor & Croatia, Biokovo Mt., Bast village & 19.6.2002 & Roman Ozimec & $1 \stackrel{+}{ }, 2$ juv. \\
\hline AR: 1276 & Kukor & Croatia, Biokovo Mt., Bast village & 29.10 .2006 & Roman Ozimec & 1 우 \\
\hline AR: 1277 & Crna Ledenica & Croatia, Biokovo Mt., Sv. Jure & 24.10 .2006 & Marko Lukić & $1 \delta^{\pi}$ \\
\hline AR: 1281 & Ledenica kod Stare škole & $\begin{array}{c}\text { Croatia, Biokovo Mt., Sv. Jure, } \\
\text { Barišna torina }\end{array}$ & 28.6.2002 & Branko Jalžić & 2 juv. \\
\hline AR: 1284 & Spasiteljica špilja & $\begin{array}{l}\text { Croatia, Biokovo Mt., Gornja Brela, } \\
\text { Bartulovići village }\end{array}$ & 23.3.2003 & Jana Bedek & 1 ㅇ \\
\hline AR: 1285 & Mala jama u stijenama & Croatia, Biokovo Mt., Kaoci & 20.6.2003 & Branko Jalžić & 1 juv. \\
\hline AR: 1286 & Kukor & Croatia, Biokovo Mt., Bast village & 6.4 .2006 & Martina Pavlek & 1 juv. \\
\hline AR: 1287 & Stonjska peć donja & Croatia, Biokovo Mt., Župa village & 27.10 .2003 & Roman Ozimec & $1 \lesssim, 1$ juv. \\
\hline AR: 1288 & Kuna špilja & Croatia, Biokovo Mt., Kadulja peak & 15.6.2002 & Roman Ozimec & 1 juv. $\widehat{0}$ \\
\hline AR: 1289 & Kukor & Croatia, Biokovo Mt., Bast village & 6.4 .2006 & Roman Ozimec & 1 juv. \\
\hline AR: 1290 & Samogorska špilja & Croatia, Biokovo Mt., Župa village & 4.4.2006 & Roman Ozimec & 1 juv. $\widehat{O}$ \\
\hline AR: 1291 & Kuna špilja & Croatia, Biokovo Mt., Kadulja peak & 28.4.2002 & Roman Ozimec & 1 juv. $\widehat{0}$ \\
\hline AR: 1292 & Jama iznad Lipog dočića & $\begin{array}{c}\text { Croatia, Biokovo Mt., Sv. Jure, Lipi } \\
\text { dočić }\end{array}$ & 26.2.2001 & Jana Bedek & 1 juv. $\hat{\jmath}$ \\
\hline AR: 1293 & Pretnerova jama & Croatia, Biokovo Mt., Radov dolac & 28.10 .2006 & Marko Lukić & 1 우 \\
\hline AR: 1294 & Crna Ledenica & Croatia, Biokovo Mt., Sv. Jure & 25.4.2004 & Branko Jalžić & $1 \uparrow, 1$ juv. $\widehat{\jmath}$ \\
\hline AR: 1296 & Kukor & Croatia, Biokovo Mt., Bast village & 27.7.2004 & Roman Ozimec & 1 우 \\
\hline AR: 1297 & Špilja u Radinovcima & $\begin{array}{c}\text { Croatia, Biokovo Mt., Zagvozd, } \\
\text { Rastovac village }\end{array}$ & 25.10 .2006 & Martina Pavlek & 2 웅, 1 §, 7 juv. \\
\hline AR: 1298 & Samogorska špilja & Croatia, Biokovo Mt., Župa village & 4.4.2006 & Helena Bilandžija & 1 우 \\
\hline AR: 1299 & Špilja u Radinovcima & $\begin{array}{c}\text { Croatia, Biokovo Mt., Zagvozd, } \\
\text { Rastovac village }\end{array}$ & 26.10 .2006 & Hrvoje Cvitanović & 2 우우, 2 juv. \\
\hline AR: 1401 & Kukor & Croatia, Biokovo Mt., Bast village & 28.7.2006 & Roman Ozimec & 1 juv. \\
\hline AR: 1402 & Matijaševa peć & Croatia, Biokovo Mt., Župa village & 19.11.2005 & Hrvoje Cvitanović & 1 juv. \\
\hline AR: 1481 & Kukor & Croatia, Biokovo Mt., Bast village & 17.8 .2000 & Roman Ozimec & $1 \stackrel{+}{1} 1$ juv. \\
\hline AR: 1495 & Kuna špilja & Croatia, Biokovo Mt., Kadulja peak & 27.8 .1998 & Roman Ozimec & 10 \\
\hline AR: 2050 & Kukor & Croatia, Biokovo Mt., Bast village & 2.1.1999 & Roman Ozimec & $1+, 1$ juv. \\
\hline AR: 2067 & Crna Ledenica & Croatia, Biokovo Mt., Sv. Jure & 24.5.2004 & Helena Bilandžija & 1 juv. $\widehat{O}$ \\
\hline AR: 2084 & Kukor & Croatia, Biokovo Mt., Bast village & 29.12.1997 & Roman Ozimec & 1 , 1 juv. \\
\hline AR: 2085 & Kukor & Croatia, Biokovo Mt., Bast village & 7.8 .2000 & Roman Ozimec & 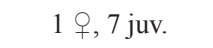 \\
\hline AR: 2088 & Kukor & Croatia, Biokovo Mt., Bast village & 25.3.2004 & Jana Bedek & 1 juv. \\
\hline AR: 2093 & Kukor & Croatia, Biokovo Mt., Bast village & 26.3.2004 & Marko Lukić & 1 \&, 1 juv. \\
\hline AR: 2104 & Čavlenovača jama & Croatia, Biokovo Mt., Radov dolac & 18.6.2002 & Roman Ozimec & 1 juv. \\
\hline AR: 2111 & Golubnjača jama & $\begin{array}{l}\text { Croatia, Biokovo Mt., Gornja Brela, } \\
\text { Bartulovići village }\end{array}$ & 23.3.2003 & Marko Lukić & 2 juv. \\
\hline
\end{tabular}




\begin{tabular}{|c|c|c|c|c|c|}
\hline AR: 2114 & Kukor & Croatia, Biokovo Mt., Bast village & 23.9.1999 & Roman Ozimec & 1 juv. \\
\hline AR: 2377 & Crna Ledenica & Croatia, Biokovo Mt., Sv. Jure & 18.6.2011 & Alen Kirin & 1 q \\
\hline AR: 3253 & Romanova jama & Croatia, Biokovo Mt., Kupušnjak & 30.9 .1995 & Roman Ozimec & 1 juv. \\
\hline AR: 3906 & Špilja u Radinovcima & $\begin{array}{c}\text { Croatia, Biokovo Mt., Zagvozd, } \\
\text { Rastovac village }\end{array}$ & 1.5 .2014 & $\begin{array}{l}\text { Branko Jalžić, } \\
\text { Petra Bregović }\end{array}$ & 2 juv. $\hat{\delta}$ \\
\hline AR: 3909 & Jama pod Svetim Jurom & Croatia, Biokovo Mt., Sv. Jure & 11.10 .2014 & Branko Jalžić & 1 juv. \\
\hline AR: 3912 & Špilja u Radinovcima & $\begin{array}{c}\text { Croatia, Biokovo Mt., Zagvozd, } \\
\text { Rastovac village }\end{array}$ & 15.10 .2014 & Petra Bregović & 1 juv. \\
\hline AR: 3915 & Kašogijeva jama & Croatia, Biokovo Mt., Sv. Jure & 11.10 .2014 & Petra Bregović & $1 q$ \\
\hline AR: 3932 & Samogorska špilja & Croatia, Biokovo Mt., Župa village & 23.1.2016 & Tin Rožman & $\begin{array}{c}1 \hat{\jmath}, 7 \text { } 7 \text { + }, 3 \text { juv. } \\
\widehat{\jmath}, 3 \text { juv. }\end{array}$ \\
\hline AR: 3933 & Samogorska špilja & Croatia, Biokovo Mt., Župa village & 23.1 .2016 & Martina Pavlek & 9 우 \\
\hline AR: 3934 & Samogorska špilja & Croatia, Biokovo Mt., Župa village & 23.1 .2016 & Marko Lukić & $\begin{array}{c}8+\uparrow, 2 \hat{\jmath}, 2 \\
\text { juv. }\end{array}$ \\
\hline AR: 3936 & Samogorska špilja & Croatia, Biokovo Mt., Župa village & 23.1 .2016 & Martina Pavlek & 3 juv., 1 juv. $\widehat{\jmath}$ \\
\hline AR: 3938 & Stonjska peć gornja & Croatia, Biokovo Mt., Župa village & 22.1 .2016 & Martina Pavlek & 2 ๆ, 1 juv. \\
\hline AR: 3941 & Stonjska peć gornja & Croatia, Biokovo Mt., Župa village & 22.1 .2016 & Martina Pavlek & 2 우우, 1 진 \\
\hline AR: 3944 & Stonjska peć donja & Croatia, Biokovo Mt., Župa village & 22.1 .2016 & Tin Rožman & 3 juv. \\
\hline AR: 3945 & Stonjska peć donja & Croatia, Biokovo Mt., Župa village & 22.1 .2016 & Tin Rožman & $1 q$ \\
\hline AR: 3947 & Stonjska peć donja & Croatia, Biokovo Mt., Župa village & 22.1 .2016 & Martina Pavlek & 5 우우 \\
\hline AR: 3949 & Kukor & Croatia, Biokovo Mt., Bast village & 21.1 .2016 & Tin Rožman & 2 우 \\
\hline AR: 3950 & Kukor & Croatia, Biokovo Mt., Bast village & 21.1 .2016 & Marko Lukić & 1 +, 4 juv. \\
\hline AR: 3953 & Matijaševa peć & Croatia, Biokovo Mt., Župa village & 23.1 .2016 & Marko Lukić & 1 +, 1 juv. \\
\hline AR: 3955 & Matijaševa peć & Croatia, Biokovo Mt., Župa village & 23.1 .2016 & Marko Lukić & 3 juv. \\
\hline AR: 3957 & Matijaševa peć & Croatia, Biokovo Mt., Župa village & 23.1 .2016 & Martina Pavlek & 2 juv. \\
\hline AR: 3973 & Stonjska peć donja & Croatia, Biokovo Mt., Župa village & 22.1 .2016 & Martina Pavlek & 1 juv. $\widehat{\jmath}, 1$ juv. \\
\hline AR: 3977 & Stonjska peć gornja & Croatia, Biokovo Mt., Župa village & 22.1 .2016 & Martina Pavlek & 1 juv. $\hat{\sigma}$ \\
\hline
\end{tabular}


PAVLEK M. \& RIBERA C., A new genus and species of Nesticidae

Appendix 3. All records of $K$. arenstorffi (Kulczyński, 1914) from the CBSS collection. Date format: dd.mm.yyyy.

\begin{tabular}{|c|c|c|c|c|c|}
\hline $\begin{array}{l}\text { CBSS coll. } \\
\text { number }\end{array}$ & Cave name & Location of the cave & $\begin{array}{l}\text { Collection } \\
\text { date }\end{array}$ & Collector & $\begin{array}{c}\text { Number and gender of } \\
\text { specimes }\end{array}$ \\
\hline AR: 823 & Jezero & Croatia, Sniježnica Mt & 28.5 .2004 & Karla Fabrio & 1 우 \\
\hline AR: 824 & Jezero & Croatia, Sniježnica Mt & 28.5 .2004 & Helena Bilandžija & 1 +, 2 juv. \\
\hline AR: 1578 & Golodražnica & $\begin{array}{l}\text { Montenegro, Bay of Kotor, } \\
\text { town of Risan }\end{array}$ & 24.4 .2010 & Jana Bedek & $2 \hat{\partial} \hat{\partial}, 2$ juv. $\hat{\partial} \hat{\partial}, 3$ juv. \\
\hline AR: 1579 & Golodražnica & $\begin{array}{l}\text { Montenegro, Bay of Kotor, } \\
\text { town of Risan }\end{array}$ & 24.4.2010 & Jana Bedek & $1 \uparrow, 1 \hat{\jmath}, 1$ juv. $\hat{\sigma}$ \\
\hline AR: 1580 & Golodražnica & $\begin{array}{l}\text { Montenegro, Bay of Kotor, } \\
\text { town of Risan }\end{array}$ & 24.4 .2010 & Alen Kirin & 1 舟, $\hat{\jmath}, 1$ juv. $\widehat{\partial}, 1$ juv. \\
\hline AR: 2777 & Jezero & Croatia, Sniježnica Mt & 16.3.2002 & Roman Ozimec & 1 +, 5 juv. \\
\hline AR: 3288 & Golodražnica & $\begin{array}{l}\text { Montenegro, Bay of Kotor, } \\
\text { town of Risan }\end{array}$ & 31.3.2012 & Ana Komerički & $2 \hat{\jmath}, 2$ 우, 1 juv. \\
\hline AR: 3291 & Golodražnica & $\begin{array}{l}\text { Montenegro, Bay of Kotor, } \\
\text { town of Risan }\end{array}$ & 31.3.2012 & Marko Lukić & $1 \stackrel{\circ}{ }, 1$ juv. $\widehat{\delta}, 1$ juv. \\
\hline AR: 3292 & Golodražnica & $\begin{array}{l}\text { Montenegro, Bay of Kotor, } \\
\text { town of Risan }\end{array}$ & 31.3.2012 & Jana Bedek & 4 우우 \\
\hline AR: 3293 & Golodražnica & $\begin{array}{l}\text { Montenegro, Bay of Kotor, } \\
\text { town of Risan }\end{array}$ & 31.3.2012 & $\begin{array}{c}\text { J. Bedek, M. } \\
\text { Lukić, A. } \\
\text { Komerički }\end{array}$ & $1 \uparrow, 1$ juv. $\widehat{\jmath}$ \\
\hline AR: 3459 & $\begin{array}{c}\text { Pećina kod Dvoriškog } \\
\text { ždrijela }\end{array}$ & Montenegro, Dragaljsko polje & 3.12 .2014 & Martina Pavlek & 10 \\
\hline AR: 3461 & $\begin{array}{c}\text { Pećina kod Dvoriškog } \\
\text { ždrijela }\end{array}$ & Montenegro, Dragaljsko polje & 3.12 .2014 & Martina Pavlek & $1 \hat{\jmath}, 2$ 우 \\
\hline AR: 3465 & Golodražnica & $\begin{array}{l}\text { Montenegro, Bay of Kotor, } \\
\text { town of Risan }\end{array}$ & 4.12 .2014 & Marko Lukić & $1 \hat{\delta}, 1$ q \\
\hline AR: 3641 & Cetinjska pećina & Montenegro, town of Cetinje & 28.10 .2015 & Martina Pavlek & 2 우, 3 ठ઼ \\
\hline AR: 3645 & Cetinjska pećina & Montenegro, town of Cetinje & 28.10 .2015 & Martina Pavlek & $1 \hat{\sigma}, 1$ 守 \\
\hline AR: 3649 & Cetinjska pećina & Montenegro, town of Cetinje & 28.10 .2015 & Vedran Sudar & $1 \hat{\jmath}, 3$ 우, 2 juv. \\
\hline AR: 3673 & Vilina pećina & Montenegro, Dragaljsko polje & 30.10 .2015 & Martina Pavlek & $1 \uparrow, 1 \lesssim$ \\
\hline AR: 3783 & Pećina Vojvode Dakovića & Montenegro, Grahovo village & 6.11 .2015 & Marko Lukić & $1 \hat{\sigma}$ \\
\hline
\end{tabular}


Appendix 4. Records of Typhlonesicus absoloni (Kratochvíl, 1933) from Cetinjska pećina from the CBSS collection. Date format: dd.mm.yyyy.

\begin{tabular}{|c|c|c|c|c|c|}
\hline $\begin{array}{l}\text { CBSS coll. } \\
\text { number }\end{array}$ & Cave name & Location of the cave & $\begin{array}{l}\text { Collection } \\
\text { date }\end{array}$ & Collector & $\begin{array}{c}\text { Number and gender of } \\
\text { specimes }\end{array}$ \\
\hline AR: 3634 & Cetinjska pećina & Montenegro, town of Cetinje & 28.10 .2015 & Jana Bedek & $1 \stackrel{\circ}{+} 1$ juv. $\hat{\jmath}$ \\
\hline AR: 3636 & Cetinjska pećina & Montenegro, town of Cetinje & 28.10 .2015 & Jana Bedek & $1 \stackrel{\circ}{ }, 1$ juv. $\overbrace{}^{\lambda}$ \\
\hline AR: 3638 & Cetinjska pećina & Montenegro, town of Cetinje & 28.10 .2015 & Tin Rožman & 2 juv. $\hat{\partial} \hat{\partial}, 1$ juv. \\
\hline AR: 3643 & Cetinjska pećina & Montenegro, town of Cetinje & 28.10 .2015 & Tin Rožman & 1 ㅇ \\
\hline AR: 3644 & Cetinjska pećina & Montenegro, town of Cetinje & 28.10 .2015 & Nikolina Kuharić & 1 juv. + \\
\hline AR: 3646 & Cetinjska pećina & Montenegro, town of Cetinje & 28.10 .2015 & Martina Pavlek & 1 juv. $\widehat{\jmath}, 1$ juv. \\
\hline AR: 3647 & Cetinjska pećina & Montenegro, town of Cetinje & 28.10 .2015 & Vedran Sudar & 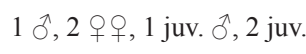 \\
\hline AR: 3768 & Cetinjska pećina & Montenegro, town of Cetinje & 8.11 .2015 & Alen Kirin & 2 juv. \\
\hline AR: 3769 & Cetinjska pećina & Montenegro, town of Cetinje & 8.11 .2015 & Marko Lukić & 3 우우 \\
\hline
\end{tabular}



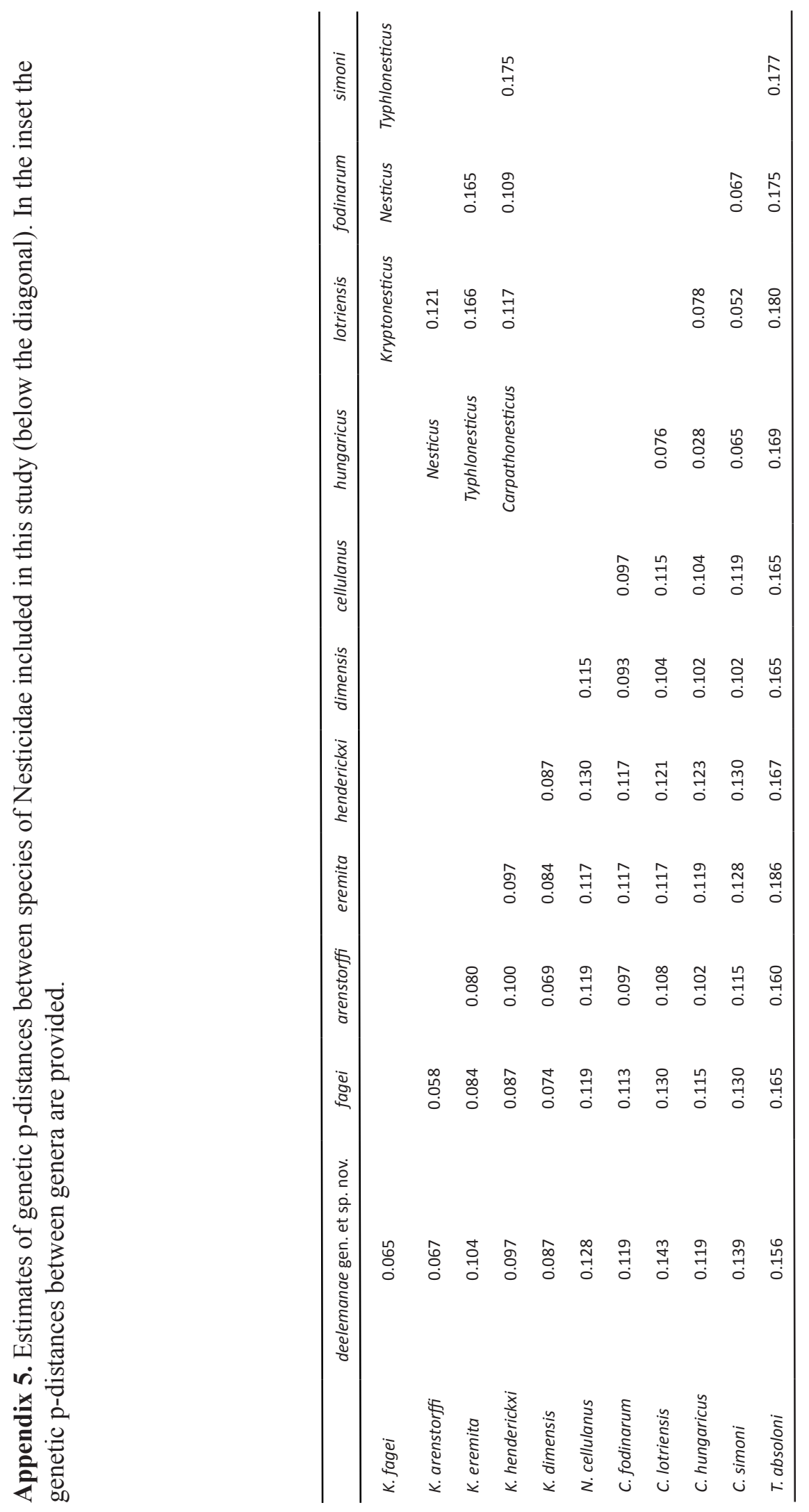